\title{
INTERNATIONAL TRADE,
} TECHNOLOGICAL SHOCKS AND SPILLOVERS IN THE

\section{LABOUR MARKET}

\section{A GVAR ANALYSIS OF THE US MANUFACTURING} SECTOR

by Paul Hiebert

and Isabel Vansteenkiste

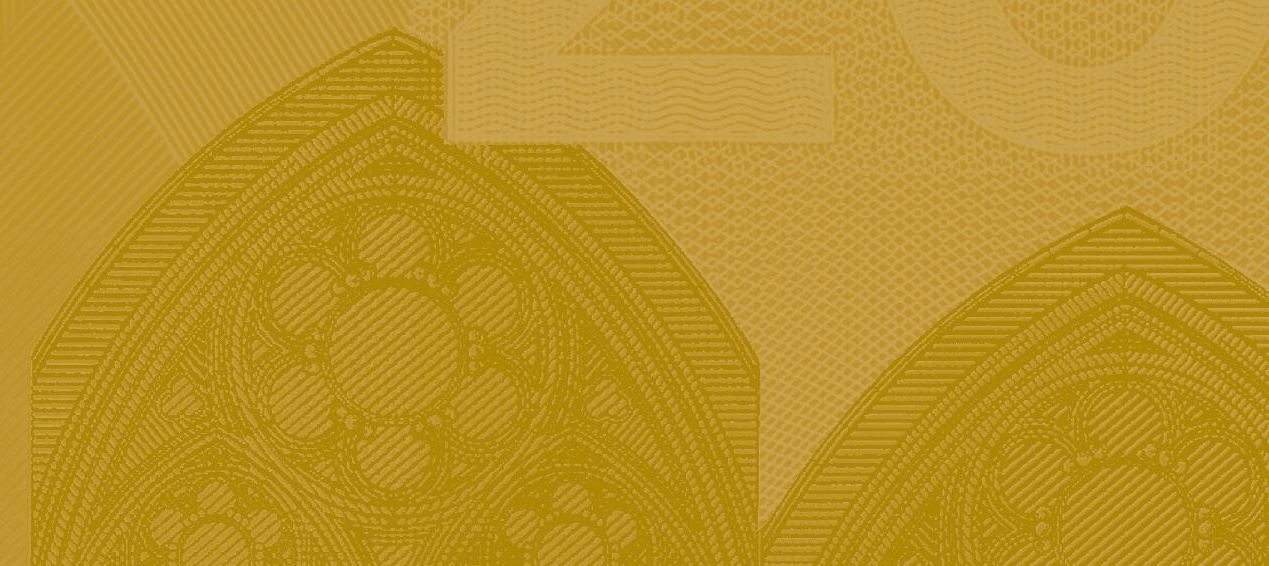


INTERNATIONAL TRADE, TECHNOLOGICAL SHOCKS AND SPILLOVERS IN THE LABOUR MARKET A GVAR ANALYSIS OF THE US MANUFACTURING SECTOR ${ }^{\prime}$

\author{
by Paul Hiebert ${ }^{2}$ \\ and Isabel Vansteenkiste ${ }^{2}$
}

This paper can be downloaded without charge from http://www.ecb.int or from the Social Science Research Network electronic library at http://ssrn.com/abstract_id $=963068$. 
(C) European Central Bank, 2007

\section{Address}

Kaiserstrasse 29

60311 Frankfurt am Main, Germany

\section{Postal address}

Postfach 160319

60066 Frankfurt am Main, Germany

\section{Telephone}

+496913440

Internet

http://www.ecb.int

Fax

+496913446000

Telex

411144 ecb d

All rights reserved.

Any reproduction, publication and reprint in the form of a different publication, whether printed or produced electronically, in whole or in part, is permitted only with the explicit written authorisation of the ECB or the author(s).

The views expressed in this paper do not necessarily reflect those of the European Central Bank.

The statement of purpose for the ECB Working Paper Series is available from the ECB website, http://www.ecb.int.

ISSN 1561-0810 (print)

ISSN 1725-2806 (online) 


\section{CONTENTS}

Abstract

Non-technical summary

1 Introduction

2 The impact of trade and technological change on the US labour market: a brief review of the literature

3 Empirical setup

3.1 The GVAR application

3.2 The data

3.3 Specification issues and integration properties

4 Results

4.1 Generalised impulse responses

4.1.1 Shock to US manufacturing sector trade openness

4.1.2 Shock to US manufacturing sector research and development spending

4.1.3 Shock to the oil price

4.1.4 Sectoral employment spillovers

4.2 Contemporaneous effects of starred variables on their sector specific counterparts

5 Concluding remarks

References

Appendices

Annex of charts

European Central Bank Working Paper Series 


\begin{abstract}
We empirically analyse the response of US manufacturing labour market variables to various shocks, notably to trade openness and technology. The econometric approach involves an application of the recently developed global VAR (GVAR) methodology of Dées, DiMauro, Pesaran, and Smith (2005) to 12 manufacturing industries over the period 1977-2003. This framework allows for an assessment of both shocks to weakly exogenous variables and intra-industry spillovers. In this vein, beyond a standard set of labour-market related variables (employment, real compensation, productivity and capital stock) and exogenous factors (a sector-specific measure of trade openness, along with common technology and oil price shocks), specific measures of manufacturing-wide variables are included for each sector. Generalised impulse responses indicate that increased trade openness negatively affects real compensation, has negligible employment effects and leads to higher labour productivity. These impacts, however, are relatively weaker those induced by technology shocks, with the latter positively and significantly affecting both real compensation and employment. There is also evidence of positive spillovers across industries from sector-specific employment and productivity shocks. Impact elasticities suggest strong intra-sectoral linkages for employment and capital stock formation, contrasting with weak linkages for what concerns real compensation and productivity.
\end{abstract}

JEL classification: F16, J01, O33.

Keywords: trade, technological change, labour market, global VAR (GVAR), impulse responses. 


\section{Non-technical summary}

There has been sizeable interest in recent years concerning the economic impacts of increasing trade integration and skill-biased technological change on the global economy. Given the reallocations of resources within and across economies implied by associated changes in trade patterns, technology and tastes, considerable effort has been devoted to gauging the impacts of trade openness and technology on the labour markets, in particular for developed economies. Much of the focus has been on the manufacturing sector of these economies, with two main arguments advanced to account for relative weakness in labour market developments within this sector vis-à-vis the overall economy. The first argument involves the attrition of low-skilled and/or low-wage jobs in certain sectors to developing countries. The second argument involves the role of skill-biased technological change, whereby an autonomous surge in technical progress has generated sectoral reallocation of production biased against primarily low-skilled workers in developed economies. These two factors are not mutually exclusive, given that trade is a channel for technology diffusion and adoption.

Theoretical arguments do not provide unequivocal predictions concerning the impacts of increased trade openness on labour market outcomes. Widely cited theories linking trade to labour market outcomes, such as Heckscher-Ohlin-Samuelson, would yield the prediction that, as trade liberalisation facilitates international specialisation in production, it should result in higher real aggregate incomes and welfare. Frictions and stickiness may imply some general deviation from these predictions in the short run -beyond any distributional issues- as the detachment of workers and capital from their original sectors may be slowed by frictional unemployment and policies impeding the efficient mobility of labour across industries. Various approaches have been followed in the empirical validation of theoretical predictions, though considerable heterogeneity in such research to date remains, and accordingly there still do not exist any definitive estimates of the effects of trade liberalisation and technological progress on labour market outcomes. That said, three broad findings within the existing empirical literature on the empirical effects of trade on labour market outcomes can be drawn. First, enhanced trade between developed and developing countries places some downward pressure on the relative returns to unskilled, low-wage workers in developed countries. Second, the direction of causality between trade and employment is not always easy to establish - though several studies report a negative relationship. Third, domestic factors are typically found to be the principal determinant of employment changes.

In this paper, we seek to quantify the extent to which relative weakness in US manufacturing labour market outcomes has derived from trade openness and technology based on a panel of 12 sectors of US manufacturing over the period 1977-2003. We examine the role of changes to industry trade openness, along with common shocks to technology and the oil price, on sectoral labour market outcomes. We also assess the role of spillovers from selected idiosyncratic shocks to individual subsectors of manufacturing. The empirical methodology is a variant of the recently developed approach of Dées, DiMauro, Pesaran, and Smith (2005), which is system approach in a panel setting allowing for the assessment of shocks to weakly exogenous factors along with an analysis of intra-sectoral spillovers. The analysis assesses the impacts of shocks to industry trade openness (proxied by the sum of exports and imports by sector), technology (proxied by research and development spending) and the oil price on a system comprised of four sector-specific endogenous variables (employment, real compensation per employee, productivity and capital stock), along with sector-specific weighted averages of other sectors of manufacturing. Such a system structure allows for interaction between productivity and labour market variables, consistent with the increasingly accepted role of international trade in shaping productivity developments. 
The results indicate that shocks to trade openness and technology have significant labour market impacts for many manufacturing subsectors, with some degree of heterogeneity in impacts, along with a role for intra-industry spillovers in the propagation of industry-specific shocks. An analysis of the dynamics of the system yields the finding that technology shocks have a more important labour market impact in the manufacturing sector over the period considered than do shocks to trade openness, in keeping with the broad thrust of existing literature. An analysis of the system dynamics in response to shocks indicates that, whilst there is some heterogeneity in industry-specific impacts to sectoral trade openness and a common technology shock, trade openness on average negatively affects real compensation and has a negligible effect on employment, whilst technology appears to positively and significantly affect both real compensation and employment. In this sense, it would suggest that higher import competition for manufacturing industries has tended to manifest itself through real wage adjustment, an effect which appears to be growing through time. Increased trade openness is also found to be associated with higher domestic productivity in the US manufacturing sector. Concerning the relationship between manufacturing industries, strong intrasectoral linkages appear to be present for employment and capital formation, contrasting with weak linkages for what concerns real compensation and productivity. Indeed, an analysis of dynamics points to some evidence of positive employment spillovers from shocks to textile sector employment and productivity in the "other transport" sector. 


\section{Introduction}

In recent years, increasing trade integration of emerging markets has intensified a long-standing debate on the effects of international trade on employment and wages in industrialised countries. At the same time, accelerating technological progress in recent years has likely been exerting some influence on labour market outcomes. For the US, employment in the manufacturing sector has been relatively weak in recent years, whilst more generally being in a position of relative secular decline when assessed against overall nonfarm employment since the mid-1970s. The relative sluggishness of manufacturing sector employment when compared with aggregate employment since the mid1990s (see Chart 1a) has been correlated with a sizeable expansion in the trade deficit in goods and services (Chart 1b) along with strong productivity gains (Chart 1c). At the same time, relatively strong productivity gains in the manufacturing sector compared with the overall economy have only been partly reflected in real compensation per hour in that sector (Chart 1d).

\section{[INSERT CHART 1]}

Two main arguments for structural weakness in industrialised countries' manufacturing sector labour market outcomes have been advanced. The first argument involves the attrition of lowskilled and/ or low-wage jobs in certain sectors to developing countries. Specifically, growing imports of labour-intensive manufactured goods from developing countries have been accompanied by considerable global corporate restructuring involving more intense use of global subsidiaries and outside contractors in the context of a greater mobility of production factors. The second argument involves the role of skill-biased technological change, whereby an autonomous surge in technical progress has generated sectoral reallocation of production biased against primarily lowskilled workers in developed economies. ${ }^{1}$ A strict dichotomy between trade and technology, however, is difficult given that the two phenomena have become progressively intertwined. As noted in Hoekman and Winters (2005), it is increasingly recognised in recent literature that trade is a channel for technology diffusion and adoption, both directly (through imports of capital goods) and indirectly (through pressure on firms exposed to trade to innovate). Research to date has offered no conclusive estimates of the effects of trade liberalisation and technological progress on labour market outcomes.

In this paper, we seek to quantify the extent to which relative weakness in US manufacturing labour market outcomes has derived from shocks to weakly exogenous factors and intra-sectoral spillovers on the basis of the recently developed global VAR (GVAR) methodology of Dées, DiMauro, Pesaran, and Smith (2005) - henceforth DdPS. The analysis is based on a panel of 12 sectors of US manufacturing applied to a system comprised of four sector-specific endogenous variables (employment, real compensation per employee, productivity and capital stock) along with several weakly exogenous variables, including industry-specific trade openness (proxied by the sum of exports and imports by sector) along with common technology (proxied by research and development, or R\&D, spending) and oil shocks; while for each sector, manufacturing-wide variables are constructed as weighted average of other sectors. ${ }^{2}$ Using such a framework we analyse the impacts of trade openness and technological shocks on labour market outcomes as well as the employment spillovers of idiosyncratic shocks emanating from sectoral variables. Moreover, the system structure of the adopted methodology allows for interaction between productivity and labour market vari-

\footnotetext{
${ }^{1}$ Separate arguments unrelated to trade or technology not analysed here include (1) there may have been a more general reduction in the share of manufactured goods in consumption through time in favour of services given demographic changes in advanced economies, such as the consumption of more medical care and the outsourcing of household tasks to various service providers (see CongressionalBudgetOffice (2004)); and (2) there may be a statistical effect of a "splintering" or "fragmentation" of services from manufacturing, whereby part of the manufacturing value added is contracted out to a separate firm and re-classified as a service (see Bhagwati, Panagariya, and Srinivasan (2004)).

${ }^{2}$ In this sense, whilst the 'GVAR' nomenclature is retained, the term 'global' applies to manufacturing sector as a whole -and not other countries/ regions- in contrast to the DdPS global model application.
} 
ables, consistent with an increasingly accepted role of international trade in shaping productivity developments.

The paper is organised as follows. We preface the analysis with a brief overview of the relevant literature in Section 2. Next, we proceed to outline the econometric estimation in Section 3. We then present the results of the econometric analysis, both in the form of generalised impulse responses and impact elasticities, in Section 4. Some concluding remarks are then drawn in Section 5.

\section{The impact of trade and technological change on the US labour market: a brief review of the literature}

Widely cited theories linking trade to labour market outcomes include those of Heckscher-OhlinSamuelson and Stolper-Samuelson along with Ricardian models. In the first two theories, comparative advantage is due to different factor intensities, whereby countries export goods that intensively utilise the factors of production with which they are relatively abundantly endowed, and import goods that use intensively factors that are relatively scarce at home. In the third theory, comparative advantage is due to relative technology differences. Despite underlying differences, all theories would argue that, as trade liberalisation facilitates international specialisation in production, it should result in higher real aggregate incomes and welfare (OECD (2005)). That said, higher trade openness may imply distributional and occupational shifts. ${ }^{3}$

Frictions and stickiness may alter the predictions of these theories, which are assumed to operate over a time period that is long enough to allow complete detachment of workers and capital from their original sectors. Indeed, in the long run trade (along with associated technological gains) would be expected to benefit the population of both emerging and developed economies through more efficient resource allocation, lower prices, more product choice and pecuniary gains from deepening specialisation and, ultimately, higher living standards. In the short run, however, some adjustment costs could result in particular related to distributional effects associated with sectoral reallocation of labour. Such adjustment costs may arise from, inter alia, frictional unemployment associated with sectoral reallocation of displaced workers and any associated need for retraining, ${ }^{4}$ and policies that impede the mobility of labour by slowing down the transfer of resources from declining to expanding activities (see Kongsrud and Wanner (2005) for an overview of such policies). ${ }^{5}$

Various approaches have been followed in the empirical validation of the above theories. A first strand of the literature has involved factor content calculations, whereby trade flows are analysed to compute the labour content of imports relative that of exports to evaluate the net impact of trade on labour markets - such as Baily and Lawrence (2004), Sachs and Shatz (1994), Wood (1995) and Wood (1998). A second strand has involved econometric analysis, such as Revenga (1992) and Grossman (1987), whereby it is empirically tested whether increasing import competition can be a major factor behind declining employment and sluggish real compensation growth in industrialised economies. A third strand has been more eclectic, involving inter alia general equilibrium models of trade, analysis of input mixes at the industry level given input mix changes in production as trade is liberalised, and the role of prices (e.g. the evolution of commodity prices over time).

Available empirical evidence has been mixed for what concerns the labour market impacts of

\footnotetext{
${ }^{3}$ In this vein, while the Stolper-Samuelson theory posits that when import-competing goods are relatively laborintensive, protection unambiguously raises real wages (see Neary (2004)), such a prediction depends importantly on whether the trade prices of labour intensive goods rise or fall in response to an openness shock, reflecting the interplay of a "lift all boats" effect versus a "redistributive" effect - see Bhagwati (1998).

${ }^{4}$ It could be argued that such costs are higher in the manufacturing sector than elsewhere as job-specific or industryspecific skills are likely more important in manufacturing firms than in service industries where skills transfer across firms and industries more easily.

${ }^{5}$ Terfous (2006) contrast a temporary adjustment effect on developed economies' labour markets (given frictions in related adjustment) with lasting effects (through changing skill-composition of the demand for labour and tradeinduced technical progress).
} 
increasing trade openness. Three main conclusions can be drawn from the extensive review of available literature within OECD (2005) and Molnar, Pain, and Taglioni (2006). First, enhanced trade between developed and developing countries places some downward pressure on the relative returns to unskilled, low-wage workers in developed countries. ${ }^{6}$ Second, the direction of causality between trade and employment is not always easy to establish (though several studies report a negative relationship). Third, domestic factors are typically found to be the principal determinant of employment changes.

Whilst several studies have found evidence that the demand for labour in developed economies particularly unskilled- may have become more elastic as a result of enhanced international openness, the literature has pointed to only a limited direct impact of trade on wages and/or employment in developed economies. Such findings, however, must be tempered by the fact that trade and technological progress may be inextricably linked, thereby introducing an indirect effect of trade on labour market outcomes. As pointed out in several papers, notably Wood (1994), Wood (1995), Wood (1998), Anderton and Oscarsson (2002), and Thoenig and Verdier (2003), international competition may lead firms in advanced economies to raise productivity by pursuing "defensive innovation", including pressure to innovate and/or alter the skill-intensity of production in response to a higher degree of trade openness. Moreover, trade may constitute a form of "technology transfer", i.e. convergence in technical efficiency within individual countries over time, particularly for trade among developed economies. ${ }^{7}$ Accounting for productivity impacts of increased trade openness, a trade-induced technology shock can either negatively or positively affect labour market outcomes, as trade may induce firms to successfully introduce productivity-enhancing technologies which do not have a definite positive or negative ex-ante labour market impact. On one hand, as noted in Amiti and Weil (2005), a positive technology shock may result in higher demand for labour due to scale effects, whilst higher productivity can lead to lower prices, generating further demand for output and labour given associated competitiveness gains. On the other hand, higher productivity can translate into job losses as the same amount of output can be produced with fewer inputs, whilst lower prices of imported inputs could lead to substitution away from domestic labour. Complicating matters further, trade does not have a clear causal effect on productivity. Whilst frictions associated with the adjustment to trade shocks may imply short-term labour market impacts which correlate with productivity, ${ }^{8}$ the causality may go in the other direction due to a composition effect, whereby more productive firms become better exporters. ${ }^{9}$

Ultimately, a lack of clear theoretical or empirical findings showing a definite impact of trade and technology on labour market outcomes motivates further empirical work on the issue. Considering the interrelations between not only key labour market variables -i.e. compensation and employment- but also trade and technology, a systems analysis also analysing dynamics induced by shocks is warranted.

\footnotetext{
${ }^{6}$ Further complicating matters, wage adjustment may be more complex in the case of increasingly fragmented production -or "task-trading" - in contrast to the production and exchange of complete goods examined in traditional trade theory. In this context Grossman and Rossi-Hansberg (2006) argue that when considering the real wage impacts of offshoring, productivity effects should be considered along with relative price and labour supply effects.

${ }^{7}$ In terms of recent studies, Cameron, Proudman, and Redding (2005) provide an empirical investigation of such effects between the US and the UK, with the finding that international trade raises rates of UK productivity growth through technology transfer but not innovation, whilst Keller and Yeaple (2005) find for the case of the US that FDI spillovers have a significant role in boosting productivity growth in the manufacturing sector though the case for import-related technology transfers is less clear.

${ }^{8}$ In particular, domestic companies subject to foreign competition may pursue internal restructuring involving layoffs and firm closures - though if such restructuring does not keep up with the decline in sales, which is plausible given adjustment costs in intensity of employment along with hiring and firing costs, this may imply falling productivity on the aggregate. Bernard, Jensen, and Schott (2006) find that plant survival and growth are negatively associated with industry exposure to low-wage country imports.

${ }^{9}$ That said, the recent studies of Bernard and Jensen (2001) and Bernard and Jensen (1999) find no evidence for a positive impact of exports on productivity for the US.
} 


\section{$3 \quad$ Empirical setup}

In this section present the empirical framework used to generate results in Section 4 in three steps. We first explain the general properties of the empirical framework. Second, we outline the data used in the empirical analysis. Third, we present information on specification issues and integration properties of the data.

\subsection{The GVAR application}

The GVAR framework of DdPS and Pesaran, Schuermann, and Weiner (2004) -henceforth PSW- is adapted to an analysis of labour market developments in the US manufacturing sector. This model explicitly allows for interdependencies that exist between sectoral and manufacturing-wide factors, allowing for an analysis of the industry effects of exogenous common or sector-specific shocks as well as an assessment of spillovers from industry-specific shocks to endogenous variables within the system.

In line with DdPS, we assume we have $N+1$ states, indexed by $i=0,1,2, \ldots, N$. For each industry, we thus assume that industry-specific variables $x$ are related to corresponding industryspecific weighted averages of the other industry's variables $x^{*}$ plus deterministic variables, such as a time trend $(t)$, industry-wide (weakly) exogenous variables and an industry-specific exogenous variable. For simplicity, we confine our exposition here to a first-order dynamic specification as in PSW. In this case we can relate the $k_{i} \times 1$ industry-specific variables, $x_{i t}=\left(p_{i t}, y_{i t}\right)$, to $x_{i t}^{*}=\left(p_{i t}^{*}, y_{i t}^{*}\right)$, the industry-wide (weakly) exogenous variables $d_{t}$ and an industry-specific exogenous variable $m_{t}$ and write:

$$
x_{i t}=a_{i o}+a_{i 1} t+\Phi_{i} x_{i, t-1}+\Lambda_{i 0} x_{i, t}^{*}+\Lambda_{i 1} x_{i, t-1}^{*}+\psi_{i 0} d_{t}+\psi_{i 1} d_{t-1}+\mu_{i 0} m_{t}+\mu_{i 1} m_{t-1}+\varepsilon_{i t}
$$

where $\Phi_{i}$ is a $k_{i} \times k_{i}$ matrix of lagged coefficients, $\Lambda_{i 0}$ and $\Lambda_{i 1}$ are $k_{i} \times k_{i}^{*}$ matrices of coefficients associated with the industry-specific variables, $\psi_{i 0}$ and $\psi_{i 1}$ are $k_{i} \times s$ matrices of coefficients associated with the common industry-wide variables, $\mu_{i 0}$ and $\mu_{i 1}$ are $k_{i} x 1$ matrices of coefficients associated with the industry-specific exogenous variable and $\varepsilon_{i t}$ is a $k_{i} \times 1$ vector of idiosyncratic industryspecific shocks. We assume in this model that the idiosyncratic shocks, $\varepsilon_{i t}$, are serially uncorrelated with mean zero and a nonsingular covariance matrix, $\Sigma_{i i}=\left(\sigma_{i i, l s}\right)$ where $\sigma_{i i, l s}=\operatorname{cov}\left(\varepsilon_{i l t}, \varepsilon_{i s t}\right)$, or written more compactly, $\varepsilon_{i t} \sim \operatorname{iid}\left(0, \Sigma_{i i}\right)$. The assumption that the industry-specific variancecovariance matrices are time invariant can be relaxed, but for the analysis of annual observations, this time invariant assumption may not be overly restrictive. This industry-specific model can now be consistently estimated separately, treating $d_{t}$ and $x_{i t}^{*}$ as weakly exogenous $I(1)$ with respect to the parameters of this model.

The weak exogeneity assumption in the context of cointegrating models implies no long-run feedbacks from $x_{i t}$ to $x_{i t}^{*}$, without necessarily ruling out lagged short-run feedbacks between the two sets of variables. In this case $x_{i t}$ is said to be long run forcing $x_{i t}^{*}$, and implies that the error correction terms of the individual industry VECMs do not enter in the marginal model of $x_{i t}^{*}$ (see DdPS). The weak exogeneity of these variables can then be tested in the context of each of the industry-specific models. Once the individual industry models are estimated all the endogenous variables need to be solved for simultaneously.

All industry-specific models together with the relations linking the (weakly) exogenous variables of the industry-specific models to the variables in the rest of the model provide a complete system. However, due to data limitations for even moderate values of $N$, a full system estimation of the model may not be feasible. To sidestep this difficulty, we follow PSW and estimate the parameters of the cross-section-specific models separately, treating the foreign industry-specific variables as weakly exogenous on the grounds that industries are small relative to the size of the overall manufacturing sector. 
Overall, the manufacturing-wide model, associated with the industry-specific models can now be given by:

$$
G x_{t}=a_{o}+a_{1} t+H x_{i, t-1}+\psi_{0} d_{t}+\psi_{1} d_{t-1}+\mu_{0} m_{t}+\mu_{1} m_{t-1}+\varepsilon_{t}
$$

where $a_{o}, a_{1}, \psi_{0}, \psi_{1}, \mu_{0}, \mu_{1}, G, H$, and $\varepsilon_{t}$ can be defined as: $(j=0$ or 1$)$

$$
a_{j}=\left(\begin{array}{c}
a_{0 j} \\
a_{1 j} \\
\ldots \\
a_{N j}
\end{array}\right) \varepsilon_{t}=\left(\begin{array}{c}
\varepsilon_{0 t} \\
\varepsilon_{1 t} \\
\ldots \\
\varepsilon_{N t}
\end{array}\right) \psi / \mu_{j}=\left(\begin{array}{c}
\psi / \mu_{0 j} \\
\psi / \mu_{1 j} \\
\ldots \\
\psi / \mu_{N j}
\end{array}\right) G=\left(\begin{array}{c}
A_{0} W_{0} \\
A_{1} W_{1} \\
\ldots \\
A_{N} W_{N}
\end{array}\right) H=\left(\begin{array}{c}
B_{0} W_{0} \\
B_{1} W_{1} \\
\ldots \\
B_{N} W_{N}
\end{array}\right)
$$

whereby $W_{i}$ is a $\left(k_{i} \times k_{i}^{*}\right) \times k$ matrix of fixed constants defined in terms of the state-specific weights. $W_{i}$ can be viewed as the link matrix that allows the state-specific models to be written in terms of the global variable vector $x_{t}$.

In general, such a GVAR model allows for interactions among the different industries through three separate but interrelated channels. First, there is a contemporaneous dependence of $x_{i t}$ on $x_{i t}^{*}$ and on its lagged values. Second, there is a dependence of the state-specific variables on common exogenous variables, such as oil and technology. Third, there is a nonzero contemporaneous dependence of shocks in industry $i$ on the shocks in industry $j$, measured via the cross-industry covariances, $\Sigma_{i j}$.

\subsection{The data}

We analyse 12 US manufacturing sectors classified according to the "International Standard Industrial Classification" (ISIC) revision 3. ${ }^{10}$ The frequency is annual, and spans the period 1977-2003 (i.e. a $T$ dimension of 25 and an $N$ dimension of 12). The endogenous sector-specific variables, $x_{i t}$, included in the model are real compensation per employee $(C O M P)$, productivity $(P R O D)$, full-time equivalent employment $(E M P L)$ and the capital stock $(C A P)$. For each sector we assume that the sector-specific variables are related to an exogenous sector-specific variables (namely trade openness, $O P E N^{11}$ ) and manufacturing-wide variables (measured as a sector-specific weighted average of the other sectors - henceforth star variables, $x_{i t}^{*}$ ). A set of deterministic variables, such as time trends $(t)$, is also included, along with common manufacturing-wide (weakly) exogenous variables $\left(d_{t}\right)$, consisting of $\mathrm{R} \& \mathrm{D}$ expenditure per employee $(R \& D)$, and the oil price $(O I L)$. The sources and the construction of the data are discussed in more detail within Appendix B.

\subsection{Specification issues and integration properties}

For all industries, the sector-specific models therefore contain the four endogenous variables, their starred counterparts, trade openness as a sector-specific weakly exogenous variable, along with R\&D and the real oil price as global, weakly exogenous variables. For each sector, we then estimate the corresponding cointegrating VAR model and determine the rank of the cointegration space. Due to data limitations, we select the lag order of the sectoral and starred variables and set both equal to one.

Our working assumption in this modelling exercise is that the country-specific star variables are weakly exogenous I(1) variables, and that the parameters of the individual models are stable over time. These long-run forcing assumptions allow us to estimate and test the long run properties of

\footnotetext{
${ }^{10}$ A 13th sector under the ISIC Classification, "Coke, refined petroleum products and nuclear fuel", is excluded given that factors autonomous from those affecting other industries likely drive its evolution relative to the other sectors.

${ }^{11}$ Trade openness is measured as the sum of exports and imports of goods by sector. Whilst alternative measures, such as tariffs, may also capture openness, industry-specific measures are not available for the full timespan of the dataset within the paper, but for the period in which there is overlap, appear to be highly correlated with the industry equivalents of the adopted measure of openness. Specifically, the average correlation coefficient between the sectoral openness variable and tariffs data (the most favoured nation definition) excluding the food sector is $73 \%$ and including the food sector $62 \%$.
} 
the different country specific models separately and consistently. Both assumptions are needed for an initial implementation of the GVAR model (see DdPS). While the GVAR methodology can be applied to integrated variables, this assumption allows us to distinguish between short- and longrun relations and interpret the long-run relations as cointegrated. Formal unit root tests suggest that all variables analysed can be considered as I(1), once accounting for possible structural breaks and other possible one-off factors. Augmented Dickey Fuller tests suggest that the hypothesis of a unit root cannot be rejected for most variables for most individual industries - as well as for the panel as a whole.

Given this set-up the rank of the cointegrating space for each sector is computed using Johansen's trace and maximal eigenvalue statistics as set out in Pesaran, Shin, and Smith (2000) for models with weakly exogenous I(1) regressors, in the case where unrestricted constants and restricted trend coefficients are included in the individual country error correction models. In most cases, we find one cointegrating relationship except in the case of the textile sector where we find two. The cointegration results are based on the trace statistic (at the $95 \%$ critical value level) which is known to yield better small sample power results compared to the maximal eigenvalue statistic. Ultimately, results from the impulse response analysis in Section 4 along with an analysis of the GVAR's eigenvalues indicate stability of the system for all shocks considered.

\section{Results}

Below we present the results of the model in two steps. First, we analyse generalised impulse responses to several exogenous shocks along with spillovers from shocks to sector-specific endogenous variables of the system. Specifically, we present the impulse responses from shocks to (i) trade openness, (ii) R\&D spending, and (iii) the oil price, and (iv) illustrate the strength of spillovers via shocks to employment in the textile sector along with productivity in the other transport sector. Second, we present contemporaneous effects of starred variables on their sector specific counterparts on the basis of impact elasticities.

\subsection{Generalised impulse responses}

In this section we make use of the Generalized Impulse Response Function (GIRF), as proposed by Koop, Pesaran, and Potter (1996) for non-linear models and developed further in Persaran and Shin (1998) for vector error-correcting models. ${ }^{12}$ In the absence of strong a priori beliefs on ordering of the variables and/or sectors in the GVAR model, the GIRFs provide useful information with respect to changes in trade openness, R\&D and employment. Although the approach is silent as to the specific structural factors behind the changes, the GIRFs can be quite informative about the dynamics of the transmission of shocks.

To study the dynamic responses of the GVAR variables to exogenous shocks along with spillovers from idiosyncratic sector-specific shocks, we investigate the implications of the following innovations:

- The employment, real compensation and productivity impacts of a one standard error positive shock to trade openness in each of the US manufacturing sector industries;

- The employment and real compensation impacts of a one standard error positive shock to $R E D$ spending in the US manufacturing sector;

\footnotetext{
${ }^{12}$ The GIRF is an alternative to the Orthongonalised Impulse Responses (OIR) of Sims (1980). The OIR approach requires the impulse responses to be computed with respect to a set of orthogonalised shocks, whilst the GIR approach considers shocks to individual errors and integrates out the effects of the other shocks using the observed distribution of all the shocks without any orthogonalisation. Unlike the OIR, the GIRF is invariant to the ordering of the variables and the countries in the GVAR model, which is clearly an important consideration given various possible alternative orderings. Even if a suitable ordering of the variables in a given country model can be arrived at from economic theory or general a priori reasoning, it is not clear how to order sectors in the application of the OIR to the GVAR model.
} 
- The employment and real compensation impacts of a one standard error positive shock to the oil price; and

- The employment spillovers emanating from two industry shocks, namely a a one standard error negative shock to employment in the textile sector along with a one standard error shock to productivity in the "other transport" sector.

Impulse responses are presented for twenty years following the imposition of a shock. Charts 2 to 5 display the bootstrap estimates of the GIRFs obtained using the sieve bootstrap procedure as reported in DdPS.

\subsubsection{Shock to US manufacturing sector trade openness}

Charts $2 \mathrm{a}$ and $2 \mathrm{~b}$ present the GIRFs of a positive one standard error shock to trade openness within that sector on employment and real compensation in US manufacturing industries. A one standard error positive shock results in a one percentage point increase in US manufacturing trade openness.

Concerning employment, an increase in sector trade openness has a mild negative or neutral impact on employment in the corresponding sector in most cases, though it is insignificant in several instances (Chart 2a). The average industry response is initially negative and small -at around $\frac{1}{20} \%$ - followed by a gradual neutralisation which brings the impact to near zero within a decade. In general, standard error bands indicate for a majority of sectors that the long-run employment impacts of such a shock is essentially absent. The dispersion of industry responses is relatively high, though heavily influenced by one clear outlier (other transport), where a positive employment impact reaching a maximum of around $\frac{1}{6} \%$ predominates. In the latter case, it is conceivable that openness has lowered the costs (e.g. via tariffs or regulatory barriers) or transport, thereby increasing its use. One key factor undepinning this development may be the evolution of the airline industry (representing the bulk of other transport) which appears to have benefited considerably from trade and is highly trade open. In general, whilst splitting production into stages (i.e. primary, secondary and tertiary production) cannot be achieved cleanly within the ISIC framework, it would appear that zero short- and longer-term impacts of openness are present for FTE employment within primary industries. The dynamics of system, whereby the initial impacts are generally highest and the effect of the shock decays through time, could be consistent with several factors, including adjustment costs in reallocating labour, frictions in varying the intensity of labour workforce in particular sectors, and a gradual loss of market share when faced with competition. Moreover, capital-labour substitution, particularly given with technology transfer associated with trade, may impart some equilibrium shifts as well as persistence in adjustment dynamics of employment to changes in openness.

Concerning real compensation, an openness shock appears to negatively impact all sectors considered with the only exception of machinery and equipment, where the impact is positive (Chart $2 \mathrm{~b}$ ). The average industry response is initially negative, with a fall in real wages of just over $1 \%$ in absolute terms, followed initially by some amplification of the response prior to a very gradual neutralisation which brings the impact to near zero within two decades. In general, standard error bands indicate significant negative impacts of trade openness on compensation, with the only exception of paper (where the impact at all horizons is effectively insignificant). In the long run, confidence intervals obtained from the standard error bands indicate the effects of openness on compensation are neutralized for all sectors except for basic metals and other transport (where it is negative), along with machinery and equipment (where it is positive). The dispersion of industry responses is relatively low, with a response of similar initial fall in wages of around one percentage point in 8 of the 12 industries. An examination of the dynamics of system indicates that, somewhat in contrast to the GIRFs for employment, a U-shaped profile in response of wages to the shock in several industries, possibly corresponding to some wage rigidity.

Analysing these results in the context of the literature in Section 2, the finding of a very limited employment response to an openness shock corroborates the basic thrust of the literature that the 
import competition effect is not the main driving force of manufacturing employment adjustments. At the same time, it does show that higher import competition appears to manifest itself through real wage adjustment. ${ }^{13}$ Such a finding, whilst consistent with low real wage growth through the mid-1990s, would also be consistent with the predictions of the Stolper-Samuelson theory. As noted in Neary (2004), improved communications may have allowed large firms to fragment their operations, moving more unskilled-labor-intensive stages of production to countries where unskilled wages are low, so lowering unskilled wages in developed countries while simultaneously raising skilled wages in developing countries. Moreover, growing openness may be having an increasingly important effect on the wage formation process in the sectors analysed. This is confirmed by comparing the outcome of the GVAR over the sample period 1977-1999 with that of 1977-2003 whereby in the latter case the impulse responses to a one standard deviation shock in the US manufacturing trade openness appear to indicate a larger effect on real compensation.

Concerning the impacts of this shock on the other endogenous variables of the GVAR, trade openness appears to exert a positive pressure on productivity, positively impacting on all sectors considered (Chart 2c). The average industry response indicates a rapid impact of increased openness on productivity, with an initially strong impact of $0.2 \%$, rising further to a peak of around $0.3 \%$ in the first two years after the shock. ${ }^{14}$ Standard error bands indicate mainly significant positive impacts of trade openness on productivity, with the only exceptions of wood, non-metallic mineral products and machinery after over a decade. The dispersion of industry responses in terms of sign is minimal, though smaller responses appear to be generally present in primary industries such as rubber, food services and non-metallic mineral products. In general, the impulse responses support the view that trade competition induces firms to successfully introduce productivity-enhancing technologies. The finding of a positive productivity impact of increased trade openness is consistent with Lawrence (2000). The latter study finds that import competition has a positive impact on US total factor productivity, mainly in skill-intensive sectors and industries competing with developing countries. This may derive from defensive innovation or also reflect firm composition, whereby in response to greater foreign competition, profit margins fall as markups decline and average productivity rises as marginal firms exit the industry (see Chen, Imbs, and Scott (2004)). Concerning the GVAR findings for the sectoral capital stock, trade openness appears to exert a positive effect as with the productivity shock, potentially lending some support for the notion of international technology transfer or defensive innovation on the part of import-competing firms.

\section{[INSERT CHARTS 2a, 2b and 2c]}

\subsubsection{Shock to US manufacturing sector research and development spending}

Charts 3a and 3b present the GIRFs of a one standard error negative shock to US manufacturing sector R\&D. This shock is equivalent to an increase of around $5 \%$ in US manufacturing R\&D spending per annum.

Concerning employment, an R\&D shock unambiguously leads to increases in all sectors considered (Chart 3a). The average response of all industries increases quite steadily from a zero response to a $1 \frac{1}{4} \%$ positive impact after a decade. An analysis of standard error bands indicates that the impacts of the technology shock are significant for 8 of the 12 sectors considered; zero impacts are only present for wood, paper products, machinery and motor. The dispersion of the results within the cases where the shock produces significant positive impacts is rather low, with an

\footnotetext{
${ }^{13}$ The finding of an initial negative impact on labour compensation is consistent with the findings reported in OECD (2005), where it is reported that large wage losses on the post-displacement job are a particularly important source of post-displacement earnings losses in the United States in contrast to Europe, where long-term unemployment and labour force withdrawal constitute a bigger source of earnings losses.

${ }^{14}$ This is somewhat stronger than the estimated impacts in Helbling, Jaumotte, and Sommer (2006) who, examining a panel of manufacturing industries in developed economies, find that a $1 \%$ increase in relative trade openness increases relative productivity by $0.12 \%$.
} 
impact in the vicinity of the above average impact for six industries, and with relatively stronger impacts on fabricated metals and other transport. An examination of the dynamics induced by the technological shock indicates that, with the exception of paper, after a small initial impact the effect gradually increases through time but generally takes less than a decade to reach its maximum impact. Such a finding could relate to adjustment costs, including the need for related investment in intangible capital, along with costs associated with rigidities in reallocating labour associated with the exploitation of new technologies.

Concerning real compensation, in contrast to the trade openness shock, an increase in $R \& D$ leads to an increase for all sectors except other transport, where it is near zero (Chart 3b). This general rise in real compensation following a period of technological progress is in line with theory as such a technology shock would be expected to increase skill premia embodied within in wages, with some frictions possibly implying sluggishness in adjustment. The average industry response is fairly high, moving from $2 \frac{1}{2} \%$ to a peak of just over $3 \%$ after only two years. An analysis of standard error bands indicates a significant response to the shock for all industries except food and other transport. The dispersion of the results is rather high, with a weak impact of technology on wages for the two latter industries contrasting with a very strong positive impact for four industries (textiles, non-metallic mineral products, basic metals and motor) of well over $5 \%$. Such a finding may possibly relate to differing skill content within the affected industries, notably heterogeneity in the adoption of new technologies or differing wage rigidities across affected industries. An analysis of the dynamics across all industries indicates a fairly rapid adjustment of compensation to technology shocks.

Concerning the impacts of this shock on the other endogenous variables of the GVAR, an R\&D shock is, as in the case of the trade openness shock, also accompanied by an increase in productivity and capital stock.

\section{[INSERT CHART 3a and 3b]}

\subsubsection{Shock to the oil price}

Charts $4 \mathrm{a}$ and $4 \mathrm{~b}$ present the GIRFs of a one standard error positive shock to the oil price. This shock is equivalent to an increase of around $20 \%$ the oil price in one year.

Concerning employment, an increase in the oil price initially depresses employment in all industries, with the exception of those with possible links to the oil price (chemical and other commodities such as basic metals and rubber), with a fairly heterogeneous long-term impact on industry employment. The average response of all industries is an initial employment loss of around $0.4 \%$, falling in absolute terms to zero after just over a decade. An analysis of standard error bands implies insignificant longer-run employment impacts of an oil shock for just over half of the industries. The dispersion of results is fairly low for most industries, where a negative impact predominates. An examination of the dynamics of the responses shows strong initial impacts for all industries except textiles; nonzero for all but four sectors. ${ }^{15}$

Concerning real compensation, an increase in the oil price depresses real compensation for all industries except the chemicals sector. The average response of all industries is a fall in real wages of around $2 \%$, similar in impact in both the short- and long-term. An analysis of standard error bands implies insignificant impacts in the long run for textiles, chemical, non-metallic mineral products and motor industries. The dispersion of responses is rather limited when excluding the positive impact within the chemical industry. The dynamics of the responses are quite varied, whilst the only non-contemporaneous impact is found in the paper industry.

Concerning the impacts of this shock on the other endogenous variables of the GVAR, the oil shock has a negative impact on productivity (on average a $20 \%$ shock lower productivity by $0.7 \%$ ) and also on the capital stock (the same shock lowers the capital stock by about $1.2 \%$ ).

\footnotetext{
${ }^{15}$ Davis and Haltiwanger (2001) find using plant level data that oil price shocks triggered considerable job reallocation and net employment adjustments for U.S. manufacturing jobs from 1972 to 1988.
} 


\section{[INSERT CHART 4a and 4b]}

\subsubsection{Sectoral employment spillovers}

In this subsection, we present sectoral employment spillovers resulting from two illustrative industryspecific shocks. First, we shock employment in the US textile sector, given a relatively high labour intensity within this sector along with its relatively elevated exposure to competitive pressures from emerging markets. Second, we shock productivity in the other transport sector, given its rather high capital content.

The GIRF results for employment of the negative shock to US textile employment is displayed in Chart 5. Overall, a one standard error shock to US textile sector employment, which amounts to a $2 \frac{1}{2} \%$ fall in the textile sector employment in the long run, reduces employment in all other sectors, with a fairly homogeneous long-term impact on industry employment. The average response of all industries is an initial employment loss of around $\frac{2}{3} \%$ followed by a maximum impact in absolute terms of nearly $1 \%$ after 5 years. An inspection of the standard error bands, however, indicates that an insignificant impact cannot be ruled out in virtually all cases. Such a finding is hardly surprising against the backdrop of possibly limited linkages of the textile sector to other industries through the production chain, though capital transfer and other such channels may be at play. The dispersion of results is declines steadily through time.

\section{[INSERT CHART 5]}

The GIRF results for employment of the positive unit shock to productivity in the "other transport" sector is displayed in Chart 6. Overall, a one standard error shock, with a maximum impact of $1 \frac{3}{4} \%$ on employment in that sector, reduces employment in all other sectors. The average response of all industries is an initial employment gain of around $\frac{3}{4} \%$ which decays steadily to settle at $\frac{1}{2} \%$ over the first decade. An inspection of the standard error bands indicates significant results are present in all cases aside from non-metallic mineral products where a zero impact following a decade cannot be ruled out. A rather stable dispersion of results indicates that the employment spillovers are positively correlated with a productivity shock in one sector.

\section{[INSERT CHART 6]}

\subsection{Contemporaneous effects of starred variables on their sector specific coun- terparts}

Table 4 presents the contemporaneous effects of the starred variables on the employment of their sectoral counterparts with robust t-ratios, computed using White's heteroscedasticity-consistent variance estimator. These values can be interpreted as impact elasticities of starred variables on their industry counterparts' employment, or spillovers. Most of them are significant and have a positive sign. They are particularly informative as regards the linkages across sectors.

- Concerning employment, the elasticities vary across sectors by between 0.16 in other transport to $0.95 \%$ in fabricated metals. Focusing on the textile sector, representing approximately the average impact within this range, we can see that a $1 \%$ change in employment in the rest of the manufacturing sector, weighted by the importance of these sectors in the textile's sector output, leads to an increase of $0.5 \%$ in employment in the textile sector within the same year. 
- Concerning the capital stock, interestingly we observe high and often significant elasticities, implying relatively strong co-movements across sectors regarding the capital stock formation, with the highest impacts in metals, motor, chemical and food.

- Concerning productivity and real compensation, elasticities are generally low and not significant. Especially on the wage side, this would suggest there is little contemporaneous 'contagion' across sectors as regards the wage formation process - indeed, the most significant impact elasticity is negative, for fabricated metals. This latter phenomenon may reflect a weak collective bargaining component of such industries over the period reviewed.

TABLE 4. Contemporaneous Effects on Employment of Starred Variables on the Sector-specific Counterparts

\begin{tabular}{|c|c|c|c|c|}
\hline & employment & productivity & real comp. & capital stock \\
\hline & 0.36 & 0.08 & -0.10 & 0.86 \\
\hline Food & $(4.30)$ & $(0.56)$ & $(-1.23)$ & $(18.59)$ \\
\hline & 0.51 & -0.04 & 0.03 & 0.28 \\
\hline Textile & $(3.32)$ & $(-0.46)$ & $(0.74)$ & $(2.61)$ \\
\hline & 0.56 & 0.07 & 0.01 & 0.02 \\
\hline Wood & $(3.96)$ & $(0.91)$ & $(0.13)$ & $(0.09)$ \\
\hline & 0.16 & 0.06 & -0.01 & 0.91 \\
\hline Chemical & $(3.79)$ & $(1.10)$ & $(-0.34)$ & $(6.58)$ \\
\hline & 0.16 & 0.05 & 0.04 & 0.98 \\
\hline Rubber & $(1.92)$ & $(0.92)$ & $(1.00)$ & $(8.94)$ \\
\hline & 0.79 & 0.09 & -0.06 & 0.19 \\
\hline Non-metallic & $(5.51)$ & $(0.70)$ & $(-0.67)$ & $(1.03)$ \\
\hline & 0.24 & 0.07 & -0.21 & 0.62 \\
\hline Basic metals & $(5.21)$ & $(0.28)$ & $(-1.79)$ & $(9.87)$ \\
\hline & 0.51 & -0.35 & 0.19 & 1.09 \\
\hline Fabricated metals & $(5.30)$ & $(-1.89)$ & $(1.26)$ & $(7.34)$ \\
\hline & 0.95 & 0.16 & -0.25 & 0.24 \\
\hline Machinery & $(3.76)$ & $(1.23)$ & $(-2.75)$ & $(5.07)$ \\
\hline & 0.84 & 0.03 & 0.00 & 0.58 \\
\hline Motor & $(4.02)$ & $(1.39)$ & $(-0.06)$ & $(8.04)$ \\
\hline & 0.86 & 0.90 & -0.09 & 0.95 \\
\hline Other transport & $(4.65)$ & $(10.68)$ & $(-0.17)$ & $(4.87)$ \\
\hline & 0.15 & -1.00 & 0.60 & 0.05 \\
\hline Nat & $(1.59)$ & $(-1.52)$ & $(1.57)$ & $(0.09)$ \\
\hline
\end{tabular}

Note: White's heteroscedastic robust t-ratios are given in round brackets.

\section{Concluding Remarks}

This paper sought to analyse the extent to which labour market developments in the US manufacturing sector over the last decades have derived from exogenous factors such as increasing sectoral trade openness along with technological change for the manufacturing sector as a whole. The empirical strategy adopted was an application of a GVAR approach, which allows for the analysis of the effects of specific exogenous shocks -notably sectoral trade openness, along with a common shock to technology (proxied by R\&D spending) and the oil price- on the endogenous variables of the system (employment, real labour compensation, productivity and the capital stock) in 12 subsectors of US manufacturing, along with an illustrative assessment of employment spillovers from industry-specific shocks to employment and productivity.

The results indicate that technological shocks seem to have a more important labour market impact in the manufacturing sector over the period considered than do shocks to trade openness, 
in keeping with the broad thrust of existing literature. An analysis of generalised impulse responses indicate that, whilst there is some heterogeneity in industry-specific impacts to sectoral trade openness and a common technology shock, trade openness on average negatively affects real compensation and has a negligible effect on employment, whilst technology appears to positively and significantly affect both real compensation and employment. In this sense, it would suggest that higher import competition for manufacturing industries has tended to manifest itself through real wage adjustment, an effect which appears to be growing through time. Increased trade openness is found to be associated with higher domestic productivity in the US manufacturing sector. Moreover, there is some evidence of positive employment spillovers from shocks to textile sector employment and productivity in the "other transport" sector. Impact elasticities indicate strong intra-sectoral linkages for employment and capital stock formation, contrasting with weak linkages for what concerns real compensation and productivity.

Several notable avenues for further research remain. First, an enhancement of the understanding of developments in recent years, involving inter alia a split of trade by partner countries so as to allow for a dichotomy of the likely differing effects of trade amongst developed economies versus between developed and emerging economies. Second, adding more economic structure to the approach may help to disentangle the direct and indirect (via productivity) labour market effects of trade. Third, the chosen approach could be applied to issue of technology shocks and spillovers across regions. Lastly, research could be broadened to consider employment dynamics in other sectors in developed economies affected by trade, notably those sectors which have seen growth in employment resulting from increased openness. 


\section{References}

Amiti, M., And S.-J. Weil (2005): "Service Offshoring, Productivity, and Employment: Evidence from the United States," IMF Working Paper, December 2005.

Anderton, R., and S. Oscarsson (2002): "Inequality, trade and defensive innovation in the USA," University of Nottingham, GEP Research Centre, Research Paper no. 2002/28.

Baily, M., and R. LAWRence (2004): "What happened to the great US job machine? The role of trade and electronic offshoring," Brookings Papers on Economic Activity, 2:2004.

Bernard, A., And J. Jensen (1999): "Exceptional exporter performance: cause, effect or both?," Journal of International Economics.

(2001): "Exporting and Productivity," NBER Working Paper Series No. 7135.

Bernard, A. B., J. B. Jensen, And P. K. Schott (2006): "Survival of the best fit: Exposure to low-wage countries and the (uneven) growth of U.S. manufacturing plants," Journal of International Economics, 68.

Bhagwati, J. (1998): "Play it again, Sam: A new look at trade and wages," Mimeo (March).

Bhagwati, J., A. Panagariya, and T. N. Srinivasan (2004): "The Muddles over Outsourcing," Journal of Economic Perspectives, Fall, 18(4).

Cameron, G., J. Proudman, and S. Redding (2005): "Technological convergence, R\&D, trade and productivity growth," European Economic Review, 49.

Chen, N., J. Imbs, And A. Scott (2004): "Competition, Globalization and the Decline of Inflation," Centre for Economic Policy Research Discussion Paper No. 4695.

CongressionalBudgetOffice (2004): "What Accounts for the Decline in Manufacturing Employment?," Economic and budget issues brief, February.

Davis, S., and J. Haltiwanger (2001): "Sectoral Job Creation and Destruction Responses to Oil Price Changes," Journal of Monetary Economics, 48.

Dées, S., F. Dimauro, H. Pesaran, and V. Smith (2005): "Exploring the international linkages of the euro area: a global VAR analysis," ECB Working Paper No. 568.

Grossman, G. M. (1987): "The Employment and Wage Effects of Import Competition in the United States," Journal of International Economic Integration, Spring.

Grossman, G. M., and E. Rossi-Hansberg (2006): "The Rise of Offshoring: It's Not Wine for Cloth Anymore," Mimeo, July.

Helbling, T., F. Jaumotte, and M. Sommer (2006): "How Has Globalization Affected Inflation?," IMF World Economic Outlook, April.

Hoekman, B., And L. A. Winters (2005): "Trade and employment: Stylized facts and research findings," Mimeo (Development Research Group, World Bank), March.

Keller, W., And S. Yeaple (2005): "Multinational enterprises international trade, and productivity growth: Firm-level evidence from the United States," Deutsche Bundesbank Discussion Paper Series 1: Economic Studies, 07.

Kongsrud, P. M., And I. Wanner (2005): "The Impact of Structural Policies on Trade-related Adjustment and the Shift to Services," OECD Economics Department Working Papers No. 42\%. 
Koop, G., H. Pesaran, and S. Potter (1996): "Impulse Response Analysis in Nonlinear Multivariate Models," Journal of Econometrics, 74.

LaWrence, R. (2000): "Does a kick in the pants get you going or does it just hurt? The impact of international competition on technological change in US manufacturing," in The Impact of International Trade on Wages (Ed.) R. C. Feenstra.

Molnar, M., N. Pain, And D. TAgLioni (2006): "The Internationalisation of Production, International Outsourcing and OECD Labour Markets," OECD Document ECO/GEN(2006)2.

NeARY, J. P. (2004): "The Stolper-Samuelson Theorem," Prepared for Encyclopedia of World Trade Since 1450, ed. J.J. McCusker et al., New York: Macmillan Reference.

OECD (2005): "Trade-adjustment Costs in OECD Labour Markets: A Mountain or a Molehill?," in OECD Employment Outlook, pp. 23-72. OECD, Paris.

Persaran, H., And Y. Shin (1998): "Generalized Impulse Response Analysis in Linear Multivariate Models," Economic Letters, 58.

Pesaran, H., T. Schuermann, and S. Weiner (2004): "Modelling Regional Interdependencies Using a Global Error-Correcting Macroeconomic Mdoe.," Journal of Business and Economic Statistics.

Pesaran, H., Y. Shin, and R. Smith (2000): "Structural Analysis of Vector Error Correction Models with Exogenous I(1) Variables," Journal of Econometrics, 97.

Revenga, A. (1992): "Exporting Jobs? The impact of import competition on employment and wages in U.S. manufacturing," The Quarterly Journal of Economics, February.

Sachs, J. D., And H. Shatz (1994): "Trade and Jobs in U.S. Manufacturing," Brookings Papers on Economic Activity, 0.

Sims, C. (1980): "Macroeconomics and Reality," Econometrica, 48.

Terfous, N. (2006): "Globalization and the labour market in the developed countries," Diagnostics Prvisions et Analyses conomiques, 96 (January).

Thoenig, M., And T. Verdier (2003): "A Theory of Defensive Skill-Biased Innovation and Globalization," The American Economic Review, 93.

Wood, A. (1994): "North-South Trade, Employment and Inequality: Changing Fortunes in a Skill-Driven World," Oxford University Press.

— (1995): "How trade hurt unskilled workers," Journal of Economic Perspectives, 9.

108. (1998): "Globalization and the rise in labour market inequalities," The Economic Journal, 


\section{Appendices}

\section{A Sectors covered}

\begin{tabular}{|l|l|}
\hline ISIC code & Industry name \\
\hline $15-16$ & Food products, beverages and tobacco \\
\hline $17-19$ & Textiles, textile products, leather and footwear \\
\hline 20 & Wood and products of wood and cork \\
\hline $21-22$ & Pulp, paper, paper products, printing and publishing \\
\hline 23 & Coke, refined petroleum products and nuclear fuel* \\
\hline 24 & Chemicals and chemical products \\
\hline 25 & Rubber and plastics products \\
\hline 26 & Other non-metallic mineral products \\
\hline 27 & Basic metals \\
\hline 28 & Fabricated metal products, except machinery and equipment \\
\hline $29-33$ & Machinery and equipment \\
\hline 34 & Motor vehicles, trailers and semi-trailers \\
\hline 35 & Other transport equipment \\
\hline
\end{tabular}

* Not included in analysis (See footnote in Subsection 3.2).

\section{B Data}

\section{PRODUCTIVITY}

Definition: Value added per worker.

Units: Index, $2000=100$. Value added divided by employment series (see definition below).

Source: OECD STAN Database for Industrial Analysis, Bureau of Economic Analysis and Bureau of Labor Statistics.

\section{EMPLOYMENT}

Definition: Total employees - Full Time Equivalent.

Units: Thousands of units.

Source: OECD STAN Database for Industrial Analysis (last update April 2005).

\section{EXPORTS}

Definition: Exports of goods.

Units: Index: $2000=100$, current price export series are measured in millions USD and deflated using value added in current and constant prices per industry.

Source: OECD STAN Database for Industrial Analysis and Bureau of Economic Analysis.

\section{IMPORTS}

Definition: Imports of goods.

Units: Index: $2000=100$, current price import series are measured in millions USD and deflated with the aid of value added in current and constant prices per industry.

Source: OECD STAN Database for Industrial Analysis and Bureau of Economic Analysis.

\section{OPENNESS}

Definition: Sum of exports and imports of goods by sector.

Units: Index (see exports and imports).

Source: OECD STAN Database for Industrial Analysis and Bureau of Economic Analysis.

OIL

Definition: West Texas Intermediate spot price deflated using the price index for personal consumption expenditures.

Units: US Dollars expressed in 2000Q1 prices.

Source: Dow Jones \& Company (oil price), Bureau of Economic Analysis (price deflator). 


\section{COMPENSATION}

Definition: Wages and salaries of employees paid by producers as well as supplements such as contributions to social security, private pensions, health insurance, life insurance and similar schemes. Units: Index: $2000=100$, nominal series are measured in millions USD and deflated with the aid of value added in current and constant prices per industry.

Source: OECD STAN Database for Industrial Analysis and Bureau of Labor Statistics.

\section{RESEARCH AND DEVELOPMENT (R\&D) SPENDING}

Definition: Analytical Business Enterprise Research and Development.

Units: Millions of USD.

Source: OECD Research and Development Expenditure in Industry database (last update April 2005).

\section{CAPITAL STOCK}

Definition: An initial capital stock is calculated for 1975. For the years following investment series are accumulated and depreciated.

Source: OECD STAN Database for Industrial Analysis and Bureau of Economic Analysis.

Calculation: (see Griliches, 1979)

$$
\begin{aligned}
K_{1978} & =I_{1978}+(1-\delta) \lambda I_{1978}++(1-\delta)^{2} \lambda^{2} I_{1978}+\ldots \\
& =I_{1978}\left(\frac{1}{1-\lambda(1-\delta)}\right)
\end{aligned}
$$

with $\lambda=\frac{1}{1+\eta}$ and $\eta$ is the mean annual growth rate of investments over the period 1970-1978. The depreciation rate $\delta$ is set to equal $13.33 \%$.

\section{Aggregation weights}

TABLE 9. Input-output table implied weights

\begin{tabular}{|c|c|c|c|c|c|c|c|c|c|c|c|c|}
\hline & $15-16$ & $17-19$ & 20 & $21-22$ & 24 & 25 & 26 & 27 & 28 & $29-33$ & 34 & 35 \\
\hline $15-16$ & 0.00 & 10.43 & 2.93 & 5.46 & 5.14 & 1.13 & 1.23 & 1.01 & 0.57 & 4.48 & 0.50 & 0.50 \\
\hline $17-19$ & 1.84 & 0.00 & 3.64 & 15.89 & 3.12 & 6.62 & 2.75 & 0.94 & 0.63 & 6.33 & 4.54 & 1.89 \\
\hline 20 & 2.43 & 3.46 & 0.00 & 14.35 & 2.23 & 1.09 & 3.59 & 2.57 & 1.12 & 8.05 & 1.08 & 0.87 \\
\hline $21-22$ & 23.75 & 23.60 & 7.82 & 0.00 & 21.19 & 9.36 & 17.80 & 7.02 & 4.97 & 43.87 & 4.07 & 3.46 \\
\hline 24 & 21.59 & 3.61 & 20.12 & 1.15 & 0.00 & 57.19 & 25.41 & 12.28 & 9.18 & 0.71 & 8.98 & 7.67 \\
\hline 25 & 12.86 & 21.57 & 7.58 & 0.70 & 17.04 & 0.00 & 7.79 & 4.68 & 3.34 & 0.61 & 8.80 & 5.07 \\
\hline 26 & 4.73 & 4.06 & 7.52 & 0.03 & 4.18 & 2.52 & 0.00 & 10.03 & 2.53 & 0.04 & 2.99 & 1.77 \\
\hline 27 & 5.49 & 0.08 & 7.51 & 0.49 & 7.28 & 4.17 & 10.15 & 0.00 & 60.78 & 4.12 & 27.20 & 16.97 \\
\hline 28 & 13.16 & 0.58 & 16.77 & 25.95 & 14.40 & 5.77 & 10.62 & 24.90 & 0.00 & 8.23 & 16.61 & 20.85 \\
\hline $29-33$ & 10.74 & 28.64 & 19.52 & 31.34 & 21.73 & 10.54 & 15.94 & 31.81 & 14.34 & 0.00 & 24.84 & 38.38 \\
\hline 34 & 2.91 & 3.95 & 6.03 & 4.63 & 3.10 & 1.37 & 4.06 & 3.86 & 2.22 & 23.53 & 0.00 & 2.57 \\
\hline 35 & 0.51 & 0.02 & 0.58 & 0.02 & 0.59 & 0.25 & 0.67 & 0.90 & 0.31 & 0.02 & 0.39 & 0.00 \\
\hline
\end{tabular}

Note: Rows and columns correspond to the ISIC revision 3 code of the relevant sector (see Appendix A for detail on the sectoral codes). 


\section{AnNeX OF ChaRts}

CHART 1. US employment, trade, productivity and compensation

Chart 1a. US postwar payroll employment millions of units (seas. adj.)

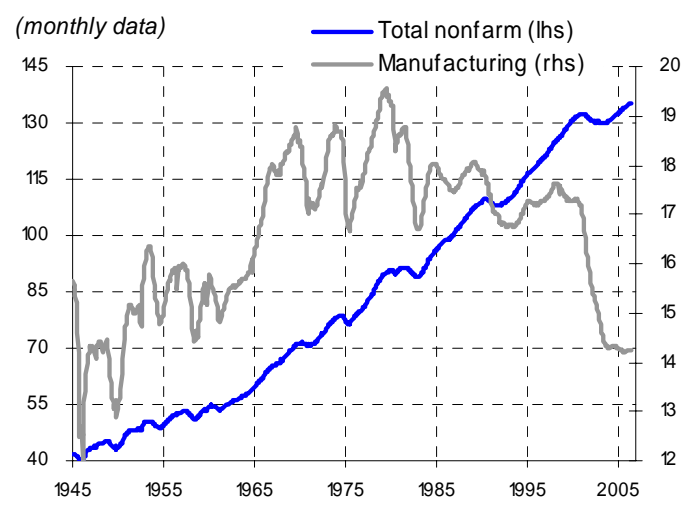

So urce: Bureau of Labo ur Statistics.

Note: Last observation refers to July 2006

Chart 1c. US output per hour year-on-year growth, $\%$

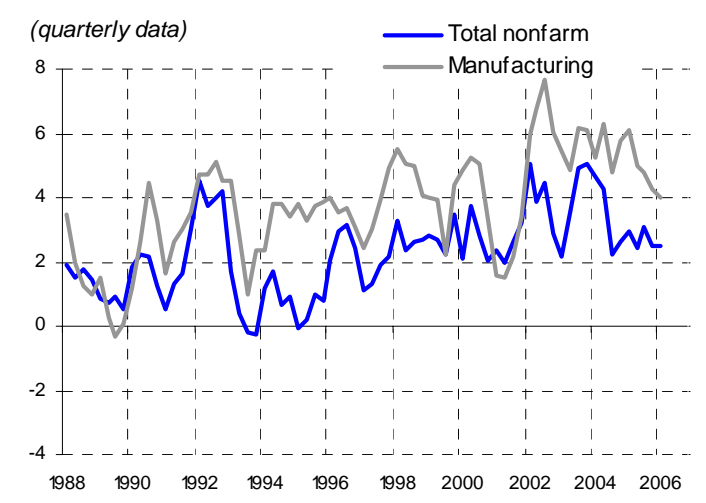

Source: Bureau of Labour Statistics.

Note: Last observation refers to 2006.Q1
Chart 1b. US real trade shares $\%$ of real GDP

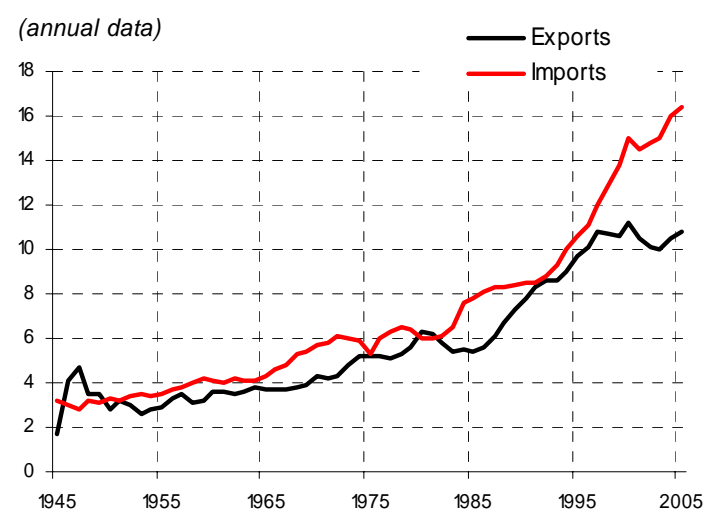

So urce: Bureau of Labo ur Statistics.

Note: Last observation refers to 2005

Chart 1d. US real hourly compensation year-on-year growth, \%

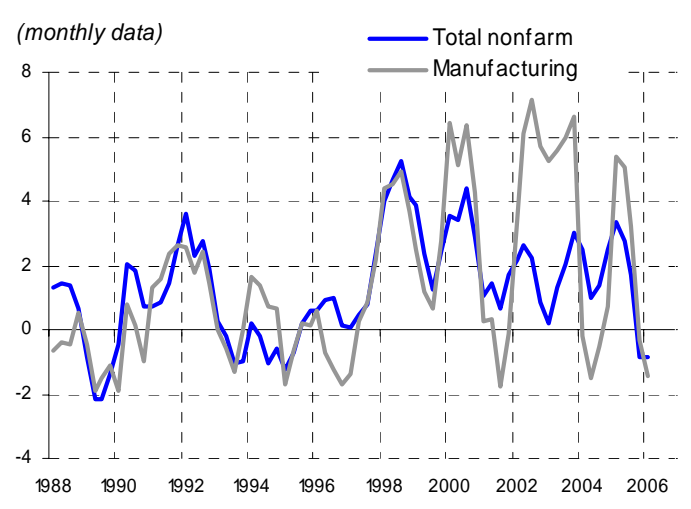

Source: Bureau of Labo ur Statistics.

Note: Last observation refers to 2006.Q1 
CHART 2. Impulse Responses of a Positive Unit (one standard deviation) Shock to US Manufacturing Trade Openness

Chart 2a. Impact on Full-time Equivalent Employment (Bootstrap Mean Estimates)
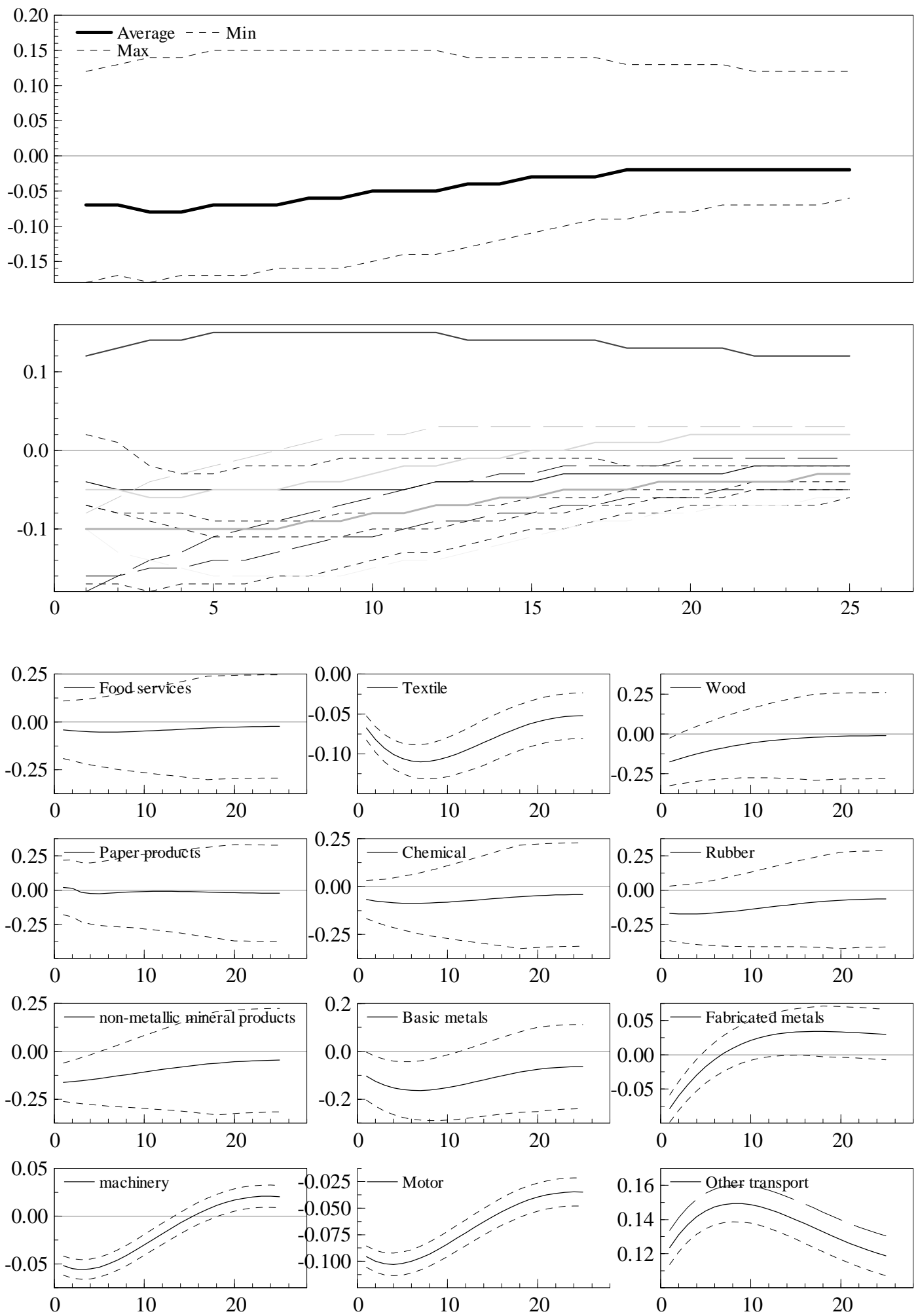

Source: Authors' calculations. 


\section{CHART 2(continued)}

Chart 2b. Impact on real compensation per employee (Bootstrap Mean Estimates)
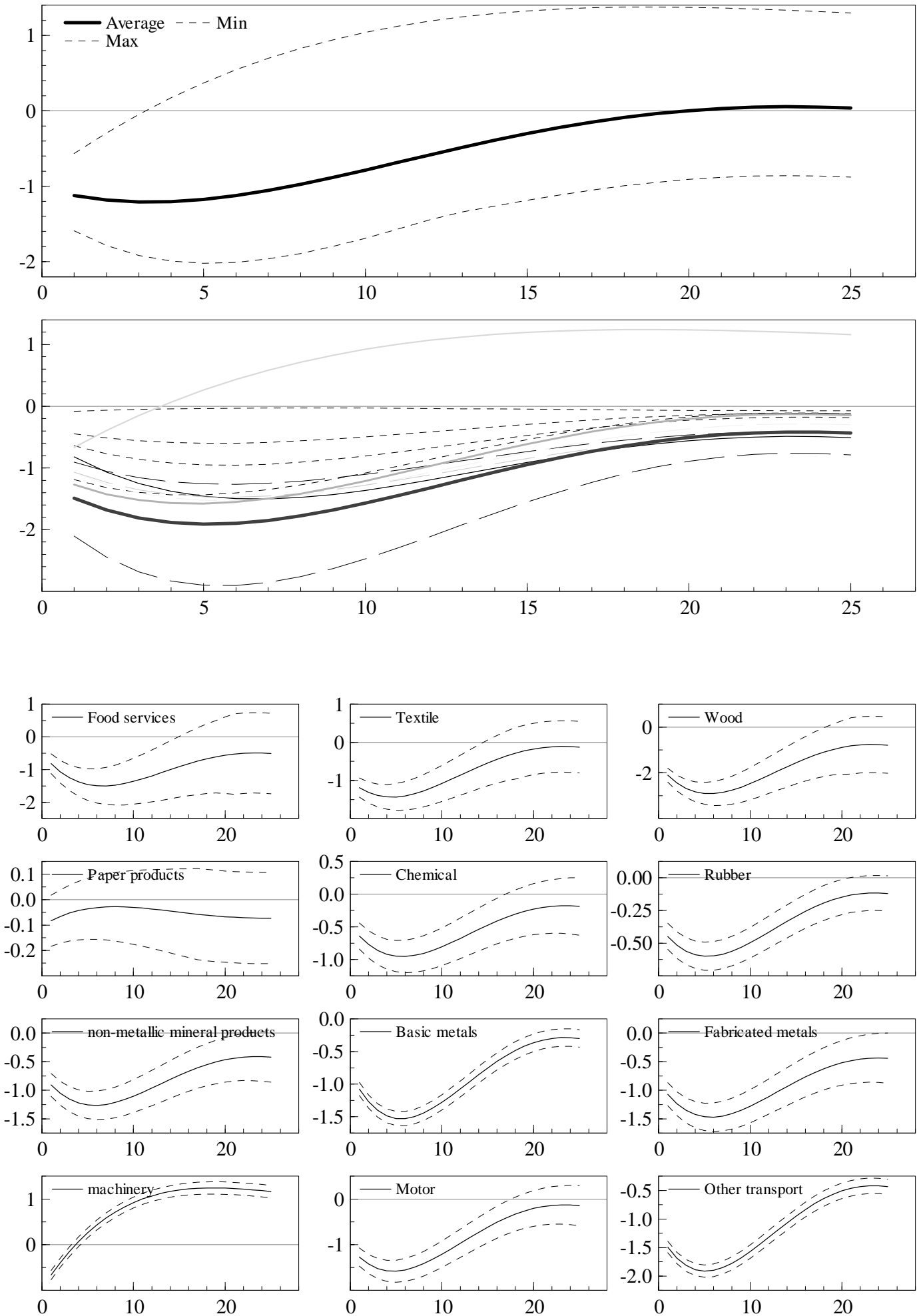

Source: Authors' calculations. 


\section{CHART 2(continued)}

Chart 2c. Impact on productivity (Bootstrap Mean Estimates)
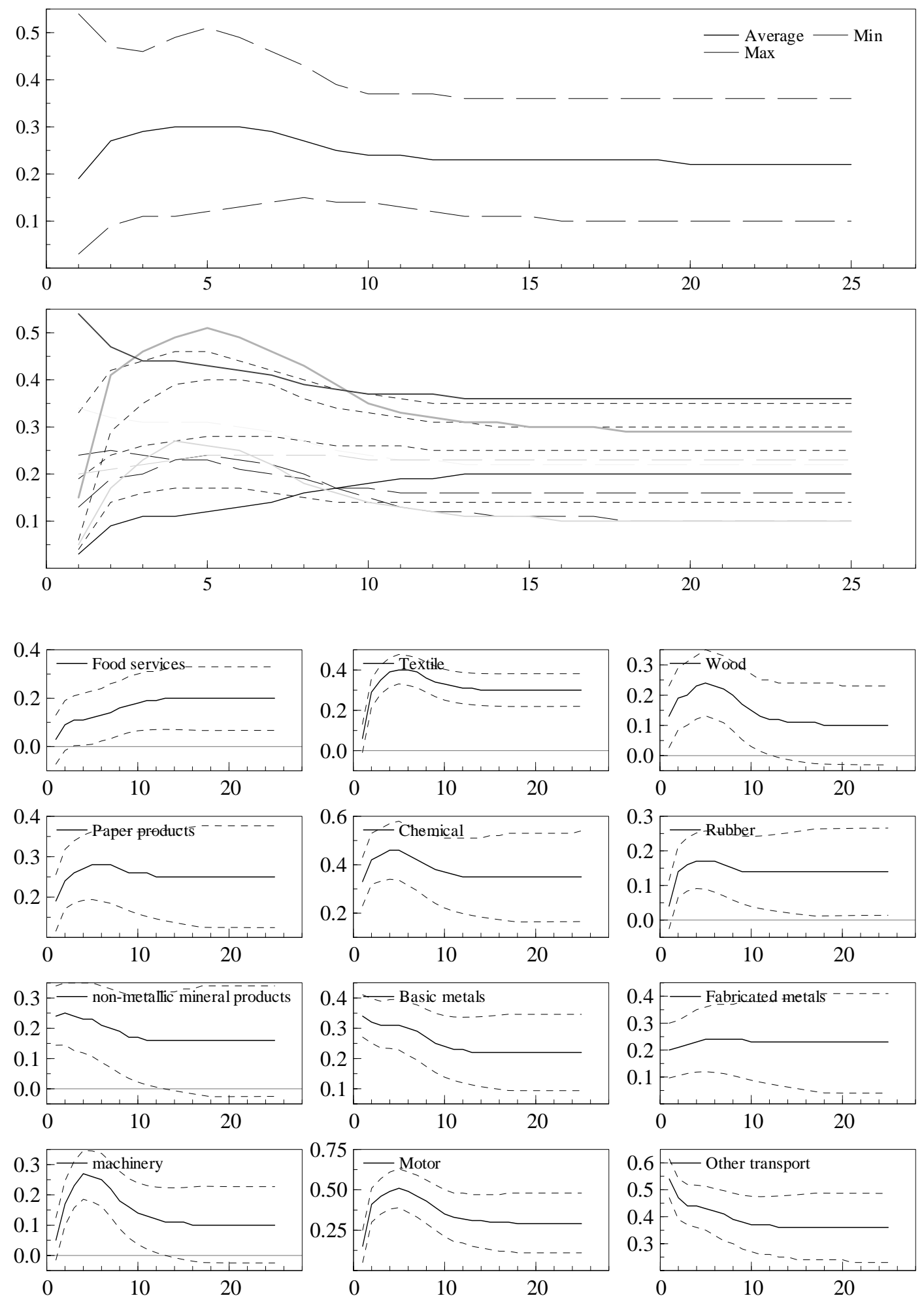

Source: Authors' calculations. 
CHART 3. Impulse Responses of a Positive Unit (one standard deviation) Shock to US Manufacturing $R \& D$

Chart 3a. Impact on Full-time Equivalent Employment (Bootstrap Mean Estimates)
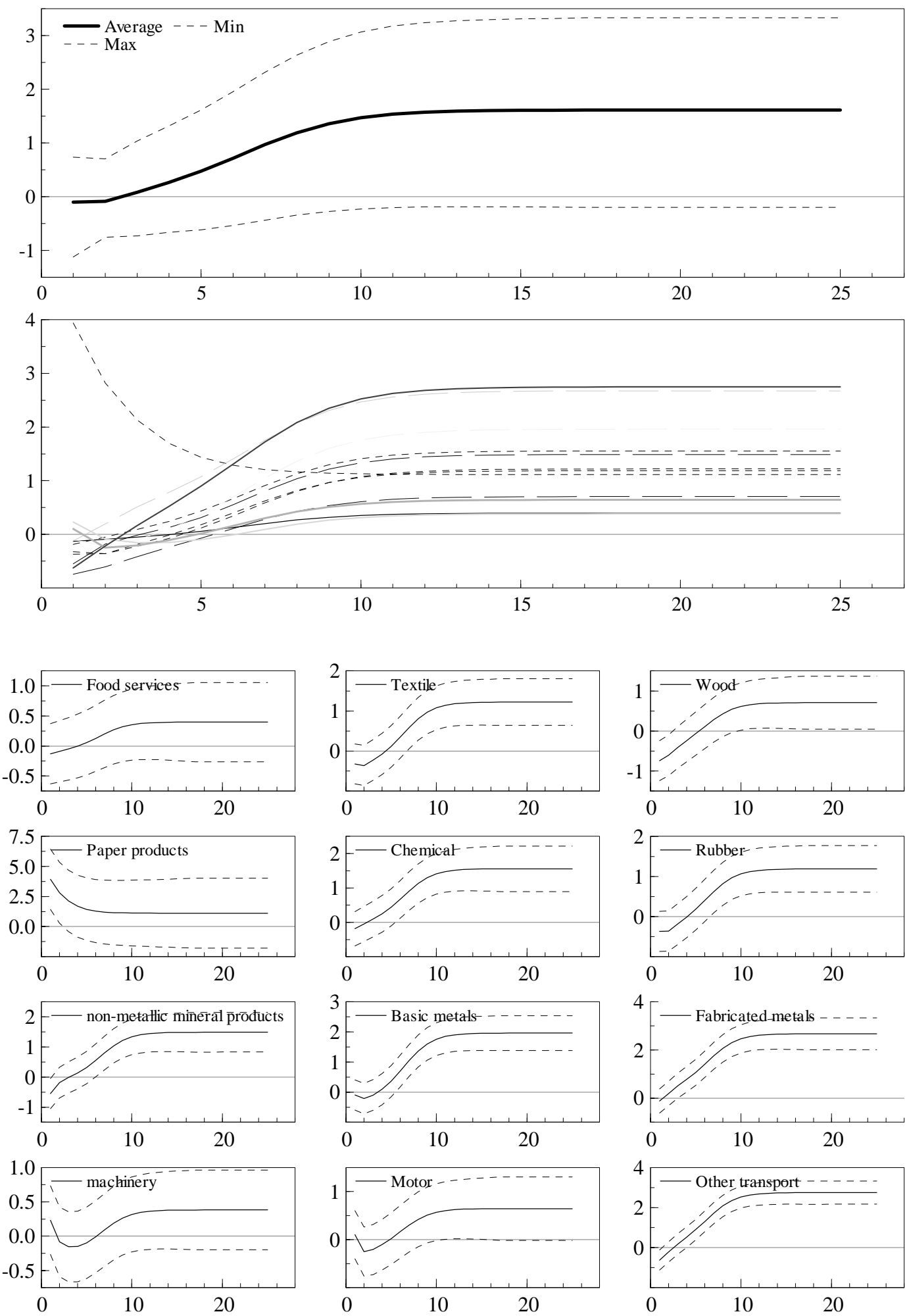

Source: Authors' calculations. 


\section{CHART 3(continued)}

Chart 3b. Impact on real compensation per employee (Bootstrap Mean Estimates)
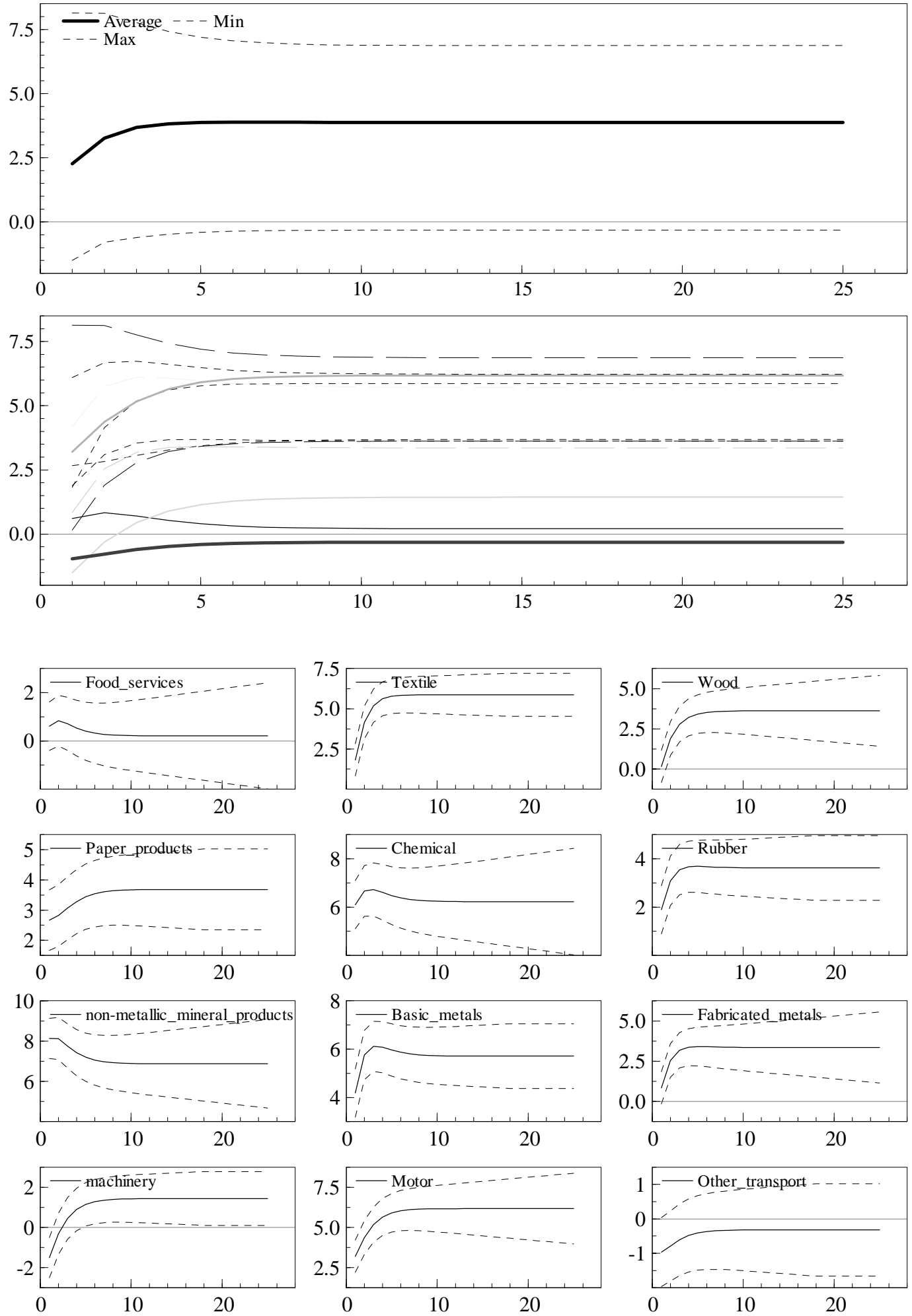

Source: Authors' calculations. 
CHART 4. Impulse Responses of a Positive Unit (one standard deviation) Shock to the Oil Price

Chart 4a. Impact on Full-time Equivalent Employment (Bootstrap Mean Estimates)
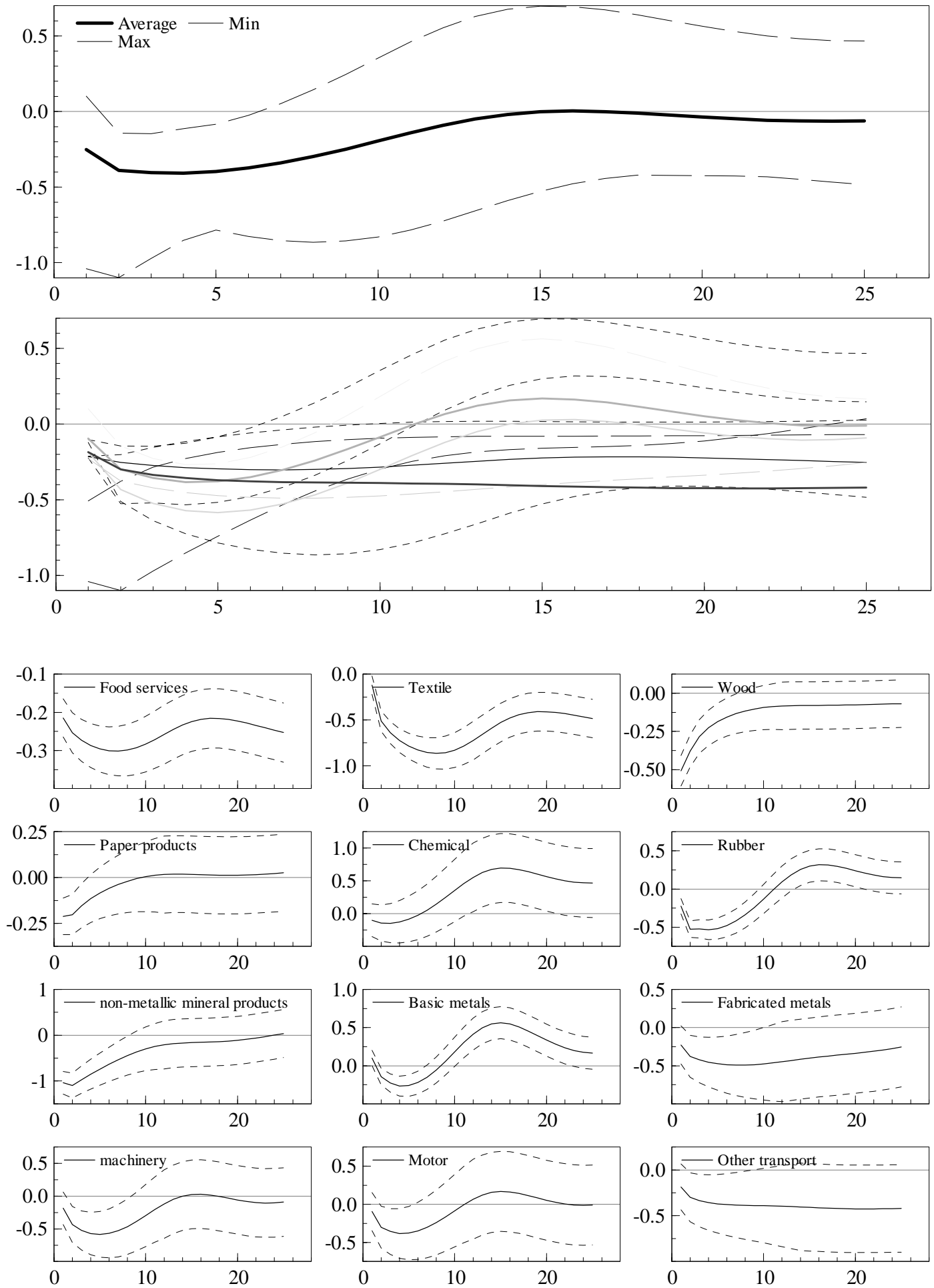

Source: Authors' calculations. 


\section{CHART 4(continued)}

Chart 4b. Impact on real compensation per employee (Bootstrap Mean Estimates)
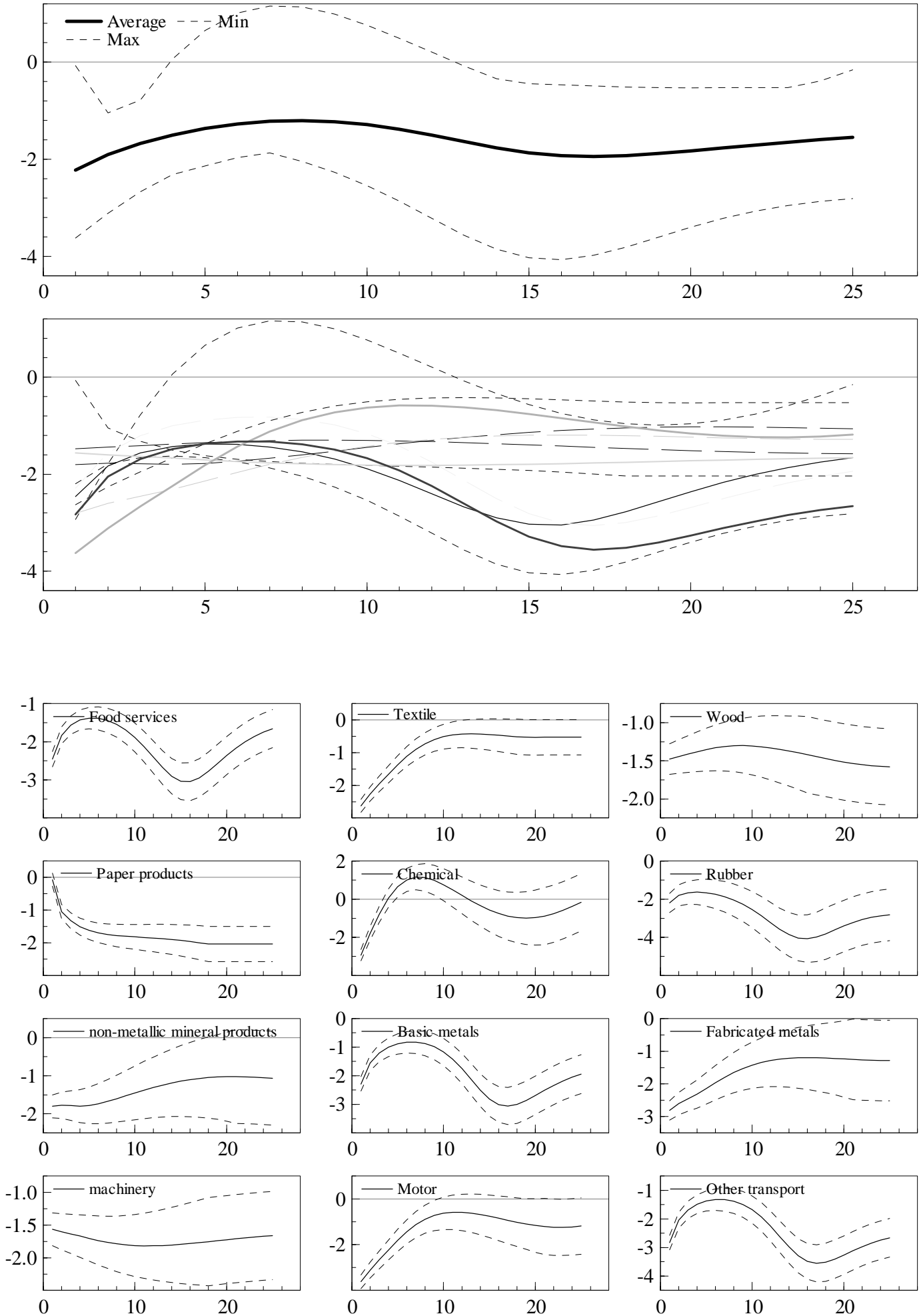

Source: Authors' calculations. 
CHART 5. Impulse Responses of a Negative Unit (one standard deviation) Shock to Employment in Textile Sector. Impact on Employment in Other Sectors (Bootstrap Mean Estimates)
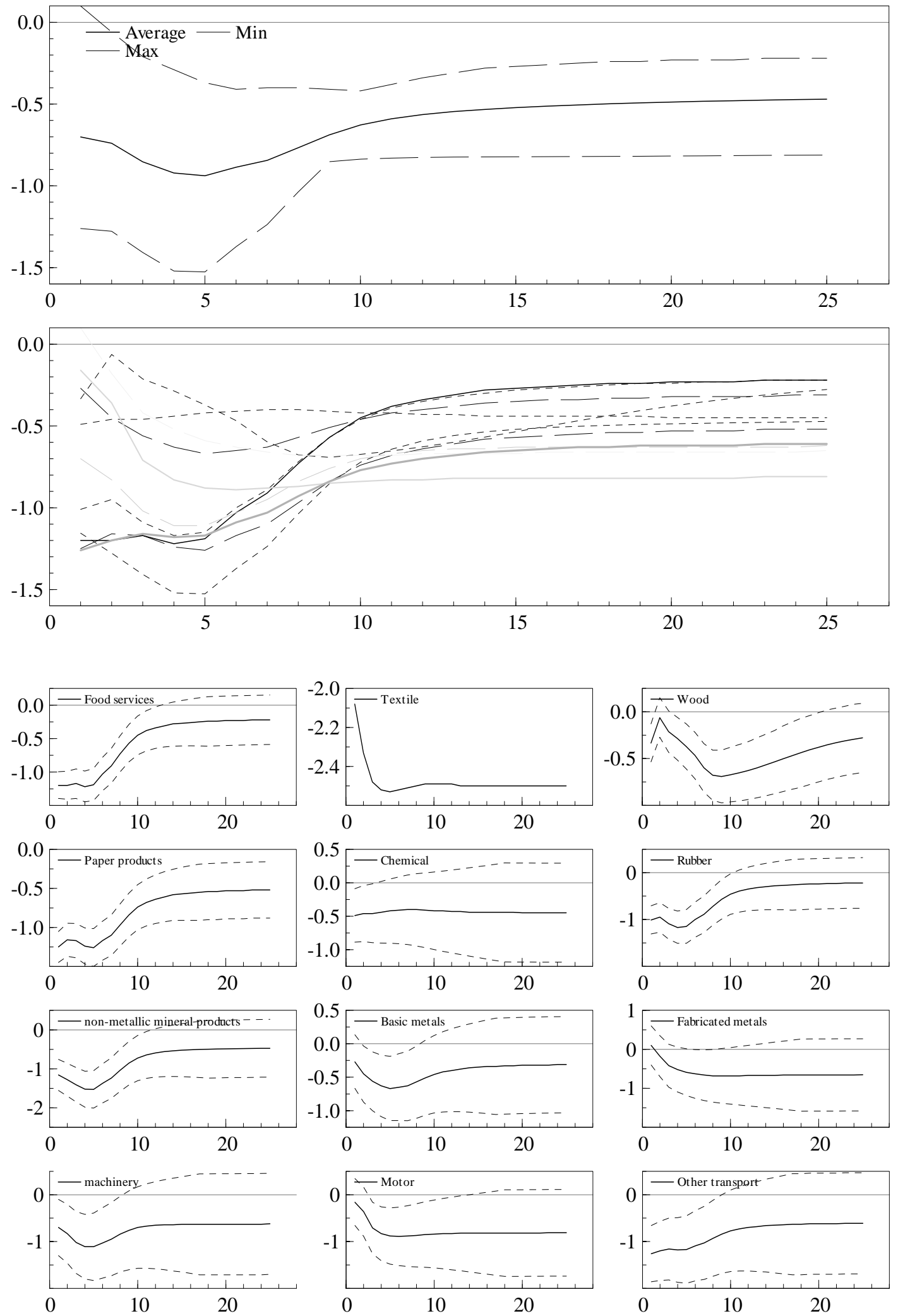

Source: Authors' calculations. 
CHART 6. Impulse Responses of a Positive Unit (one standard deviation) Shock to US Productivity in "Other Transport" Sector. Impact on Employment in Other Sectors (Bootstrap Mean Estimates)
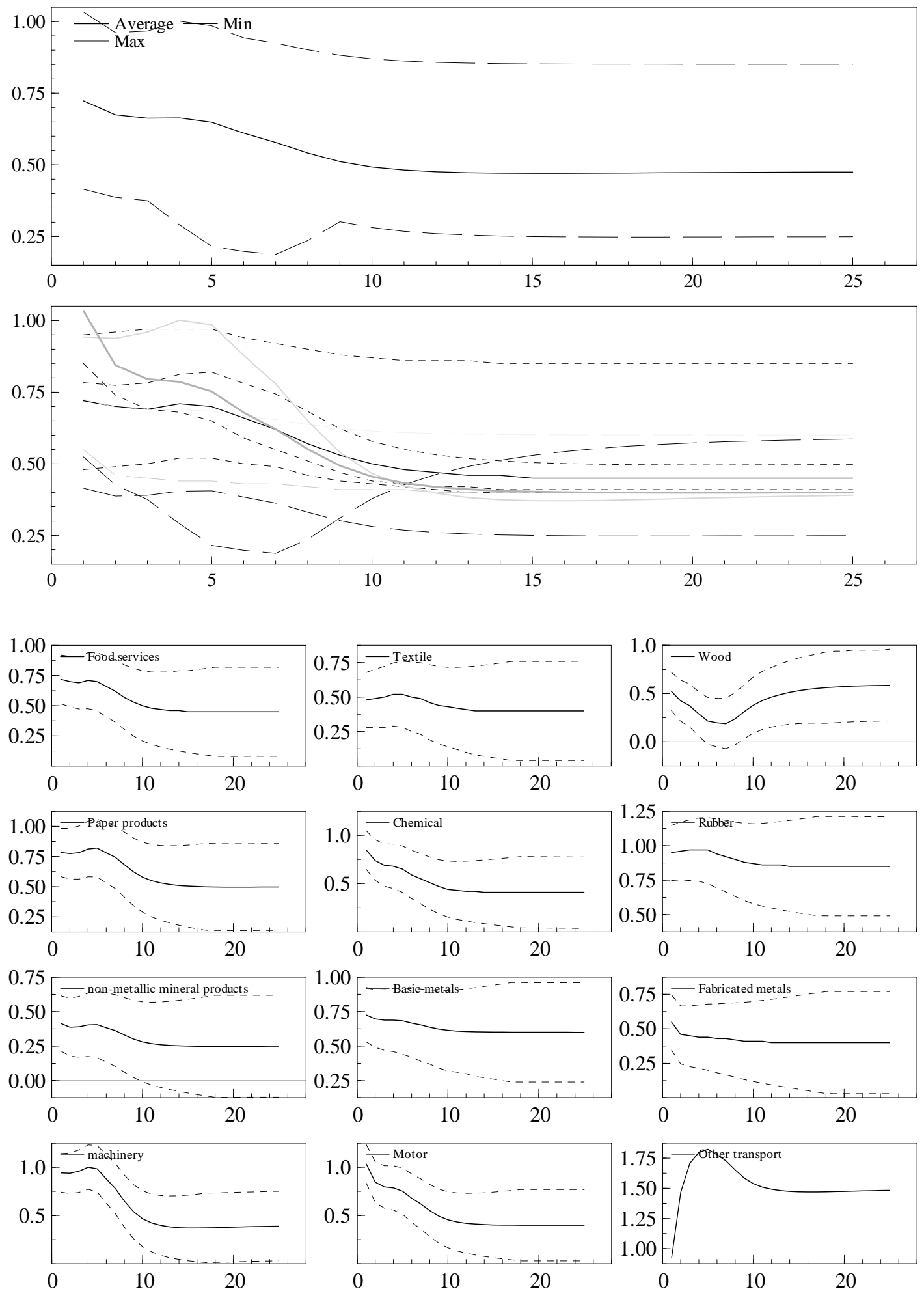

Source: Authors' calculations. 


\section{European Central Bank Working Paper Series}

For a complete list of Working Papers published by the ECB, please visit the ECB's website (http://www.ecb.int)

691 "The yield curve as a predictor and emerging economies" by A. Mehl, November 2006.

692 "Bayesian inference in cointegrated VAR models: with applications to the demand for euro area M3" by A. Warne, November 2006.

693 "Evaluating China's integration in world trade with a gravity model based benchmark" by M. Bussière and B. Schnatz, November 2006.

694 "Optimal currency shares in international reserves: the impact of the euro and the prospects for the dollar" by E. Papaioannou, R. Portes and G. Siourounis, November 2006.

695 "Geography or skills:What explains Fed watchers' forecast accuracy of US monetary policy?" by H. Berger, M. Ehrmann and M. Fratzscher, November 2006.

696 "What is global excess liquidity, and does it matter?" by R. Rüffer and L. Stracca, November 2006.

697 "How wages change: micro evidence from the International Wage Flexibility Project" by W.T. Dickens, L. Götte, E. L. Groshen, S. Holden, J. Messina, M. E. Schweitzer, J.Turunen, and M. E.Ward, November 2006.

698 "Optimal monetary policy rules with labor market frictions" by E. Faia, November 2006.

699 "The behaviour of producer prices: some evidence from the French PPI micro data" by E. Gautier, December 2006.

700 "Forecasting using a large number of predictors: Is Bayesian regression a valid alternative to principal components?" by C. De Mol, D. Giannone and L. Reichlin, December 2006.

$70 \mathrm{I}$ "Is there a single frontier in a single European banking market?" by J.W. B. Bos and H. Schmiedel, December 2006.

702 “Comparing financial systems: a structural analysis” by S. Champonnois, December 2006.

703 "Comovements in volatility in the euro money market" by N. Cassola and C. Morana, December 2006.

704 "Are money and consumption additively separable in the euro area? A non-parametric approach" by B. E. Jones and L. Stracca, December 2006.

705 "What does a technology shock do? A VAR analysis with model-based sign restrictions" by L. Dedola and S. Neri, December 2006.

706 'What drives investors' behaviour in different FX market segments? A VAR-based return decomposition analysis" by O. Castrén, C. Osbat and M. Sydow, December 2006.

707 "Ramsey monetary policy with labour market frictions" by E. Faia, January 2007.

708 "Regional housing market spillovers in the US: lessons from regional divergences in a common monetary policy setting" by I.Vansteenkiste, January 2007.

709 "Quantifying and sustaining welfare gains from monetary commitment" by P. Levine, P. McAdam and J. Pearlman, January 2007. 
710 "Pricing of settlement link services and mergers of central securities depositories" by J.Tapking, January 2007.

7 II "What "hides” behind sovereign debt ratings?" by A.Afonso, P. Gomes and P. Rother, January 2007.

712 “Opening the black box: structural factor models with large cross-sections” by M. Forni, D. Giannone, M. Lippi and L. Reichlin, January 2007.

7I3 “Balance of payment crises in emerging markets: How early were the "early" warning signals?" by M. Bussière, January 2007.

714 “The dynamics of bank spreads and financial structure” by R. Gropp, C. Kok Sørensen and J.-D. Lichtenberger, January 2007.

715 “Emerging Asia's growth and integration: How autonomous are business cycles?” by R. Rüffer, M. Sánchez and J.-G. Shen, January 2007.

716 “Adjusting to the euro” by G. Fagan and V. Gaspar, January 2007.

717 "Discretion rather than rules? When is discretionary policy-making better than the timeless perspective?" by S. Sauer, January 2007.

718 “Drift and breaks in labor productivity” by L. Benati, January 2007.

719 “US imbalances: the role of technology and policy” by R. Bems, L. Dedola and F. Smets, January 2007.

720 "Real price wage rigidities in a model with matching frictions" by K. Kuester, February 2007.

721 “Are survey-based inflation expectations in the euro area informative?" by R. Mestre, February 2007.

722 "Shocks and frictions in US business cycles: a Bayesian DSGE approach" by F. Smets and R.Wouters, February 2007.

723 “Asset allocation by penalized least squares” by S. Manganelli, February 2007.

724 “The transmission of emerging market shocks to global equity markets” by L. Cuadro Sáez, M. Fratzscher and C. Thimann, February 2007.

725 "Inflation forecasts, monetary policy and unemployment dynamics: evidence from the US and the euro area" by C. Altavilla and M. Ciccarelli, February 2007.

726 "Using intraday data to gauge financial market responses to Fed and ECB monetary policy decisions" by M.Andersson, February 2007.

727 "Price setting in the euro area: some stylised facts from individual producer price data", by P.Vermeulen, D. Dias, M. Dossche, E. Gautier, I. Hernando, R. Sabbatini and H. Stahl, February 2007.

728 "Price changes in finland: some evidence from micro cpi data", by S. Kurri, February 2007.

729 "Fast micro and slow macro: can aggregation explain the persistence of inflation?", by F. Altissimo, B. Mojon and P. Zaffaroni, February 2007.

730 "What drives business cycles and international trade in emerging market economies?", by Marcelo Sánchez , February 2007.

73I "International trade, technological shocks and spillovers in the labour market: A GVAR analysis of the US manufacturing sector”, by P. Hiebert and I.Vansteenkiste, February 2007. 


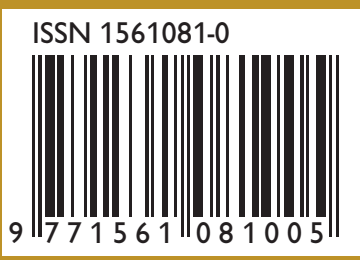

